\title{
Understanding the Relationship Between Sleep Problems in Early Childhood and Borderline Personality Disorder: A Narrative Review
}

\author{
Isabel Morales-Muñoz (iD) 1,2 \\ Buse Beril Durdurak' \\ Ayten Bilgin ${ }^{3}$ \\ Steven Marwaha ${ }^{1,4}$ \\ Catherine Winsper 5 \\ 'Institute for Mental Health, School of \\ Psychology, University of Birmingham, \\ Birmingham, UK; ' ${ }^{2}$ Department of Public \\ Health Solutions, Finnish Institute for \\ Health and Welfare, Helsinki, Finland; \\ ${ }^{3}$ School of Psychology, University of Kent, \\ Canterbury, UK; ${ }^{4}$ The Barberry National \\ Centre for Mental Health, Birmingham \\ and Solihull Mental Health Trust, \\ Birmingham, UK; ${ }^{5}$ Coventry and \\ Warwickshire Partnership NHS Trust, \\ Research and Innovation, Coventry, UK
}

Correspondence: Isabel Morales-Muñoz Institute for Mental Health, School of Psychology, University of Birmingham, 52 Pritchatts Road, Birmingham, BI5 2TT, UK

Email I.Morales-Munoz@bham.ac.uk
Objective: Recent research indicates that sleep problems in childhood precede the development of borderline personality disorder (BPD) symptoms, but the mechanisms by which sleep problems associate with BPD are still unknown. This narrative review aims to provide some potential explanations for how early sleep problems might associate with BPD.

Methods: We used the biosocial developmental model of BPD as a framework to discuss how sleep problems may associate with BPD. Articles were identified via PubMed and Embase, and papers published between January 1991 and April 2021 were extracted. Authors made a series of literature searches using the following keywords: Sleep problems, Insomnia, Nightmares, Hypothalamic-Pituitary-Adrenal Axis (HPA), Prefrontal Cortex, Family Psychopathology, Disrupted Attachment, Child Maltreatment, Impulsivity, Emotion Regulation, Internalizing, Externalizing, Rumination, Childhood, Adolescence, Young people. The inclusion criteria were published in peer-reviewed journals; human studies or reviews; published in English. The exclusion criteria were commentaries; abstracts from conferences; studies with animal samples. A total of 96 articles were included for the purpose of this review.

Results: The evidence from this review suggests that some biological factors and core features of BPD act as potential mechanisms mediating the associations between early sleep and subsequent BPD, while some family-related factors might constitute common risk factors for sleep problems and BPD.

Conclusion: The biosocial developmental model of BPD provides a plausible characterization of how sleep disruption might lead to subsequent BPD. Further research on new developmental and early intervention approaches to understand how sleep in early stages associates with BPD could have significant clinical impact on these patients and could inform targeted therapeutic interventions.

Keywords: sleep, borderline personality disorder, biosocial developmental model, childhood, adolescence, mechanisms

\section{Introduction}

Borderline Personality Disorder (BPD) is characterized by emotional instability, impulsivity, disturbed cognition, sleeplessness and states of high inner tension. Sleep problems are common in BPD and exacerbate some core symptoms, such as emotional dysregulation (ie, the inability to flexibly respond to and manage emotions). ${ }^{1}$ However, the nature of the associations between sleep problems and BPD needs exploration and is also characterized by lack of specificity (eg, sleep also associates with other mental disorders, such as depression). ${ }^{2}$ Therefore, further 
research is required to understand the specific role of sleep in the development and exacerbation of BPD.

It is possible that sleep problems may precede the development of BPD. Findings from two recent longitudinal studies have provided support for the existence of prospective associations between sleep problems in childhood and subsequent BPD symptoms in adolescence. First, it was shown that persistent nightmares in childhood (ie, at 2.5, 3.5, 4.8 and 6.8 years of age) were associated with more BPD symptoms in adolescence. ${ }^{3}$ Second, shorter sleep duration at 3.5 years was prospectively associated with the development of BPD symptoms in adolescence. ${ }^{4}$ Therefore, emerging evidence suggests that nightmares and specific sleep problems occurring in early childhood are prospectively associated with the development of BPD symptoms in adolescence, at least in the general population. However, the potential mechanisms/factors underlying the associations between early sleep problems and BPD are still unknown.

The biosocial developmental model of borderline personality ${ }^{5}$ provides a framework, which helps to understand the development of BPD. In this model, the authors suggest one probable pathway that leads to BPD, which begins with early vulnerability, expressed initially as impulsivity and followed by heightened emotional sensitivity. These vulnerabilities are then potentiated across development by environmental risk factors that give rise to more significant and functionally damaging emotional, behavioral, and cognitive dysregulation. In this model, several biological correlates, psychosocial risk factors and etiological hypotheses are presented. Therefore, we will use this model as a framework to discuss how sleep problems might associate with the development of BPD. More specifically, we will focus on the factors (ie, biological, psychosocial and core features) from the model with the strongest evidence for the development of BPD and that also have links with early sleep problems. Therefore, among the biological correlates, we will focus on the hypothalamic-pituitary-adrenal axis (HPA) and prefrontal cortex. Among the psychosocial risk factors, we will focus on family psychopathology, disrupted attachment and childhood maltreatment. Finally, among the core features of BPD, we will focus on impulsivity, emotion regulation, and internalizing (eg, sadness, anxiety or loneliness) and externalizing (eg, aggression or hyperactivity) symptoms. Thus, this article reviews the links between early sleep and each of these factors, as potential mechanisms and/or contributing factors explaining the association between sleep problems and subsequent BPD, and aims to answer the following research questions:

(1) What is the association between sleep and HPA in adolescence and childhood?

(2) What is the impact of sleep on the prefrontal cortex in young adulthood, adolescence and childhood?

(3) What is the association between sleep and family psychopathology in early childhood?

(4) How do sleep and disrupted attached interact in early childhood?

(5) What is the impact of childhood maltreatment on sleep in childhood, adolescence and young adulthood?

(6) What is the link between sleep and impulsivity in young adulthood, adolescence and childhood?

(7) What is the association between sleep and emotional regulation in young adulthood, adolescence and childhood?

(8) How do sleep and internalizing/externalizing symptoms associate in adolescence and childhood?

\section{Method}

A literature search was conducted via PubMed and Embase for studies published between January 1991 and April 2021. IMM and BD conducted a series of literature searches, using the following keywords in indexed fields: 'Sleep problems', "Insomnia", "Nightmares", "HPA", "prefrontal cortex", "family psychopathology", "disrupted attachment", "child maltreatment", "impulsivity", "emotion regulation", "internalizing", "externalizing" and "rumination", together with "childhood", "adolescence", "young people". The keywords of sleep problems OR insomnia OR nightmares AND childhood OR adolescence OR young people, together with one of the correlates, separately, were used in all possible permutations, and abstracts from the results of searches were assessed. Selected papers had to meet the following criteria: (1) published in peer-reviewed journals; (2) human studies or reviews on the related topic; (3) published in English. The exclusion criteria were (1) commentaries; (2) abstracts from conferences; (3) studies with animal samples. In the next step, the full text of eligible articles was obtained and assessed. After a full-text assessment of all articles by the research team, their inclusion was subjected to open discussion by the research team. Finally, a total of 96 articles were included for the purpose of this review. See Figure 1 for details of the search and selection strategy. 


\section{Overlapping Biological Correlates of BPD and Sleep \\ Sleep and Hypothalamic-Pituitary-Adrenal Axis}

The HPA axis represents a key stress response system, and growing evidence suggests that it is dysfunctional in the BPD population. ${ }^{6}$ Further, sleep, and in particular deep sleep, has an inhibitory influence on the HPA axis, whereas activation of the HPA can lead to sleeplessness. ${ }^{7}$

What is the Association Between Sleep and HPA in Adolescence and Childhood?

In adolescents, the existing studies on the topic have focused on actigraphy-based measures. For instance, in a cross-sectional study with 19-year-old healthy adolescents $(\mathrm{N}=119)$, longer sleep duration was related to steeper decline in cortisol. ${ }^{8}$ Another study conducted in 265 participants with a mean age of 12.3 years old reported that actigraph-based sleep duration and sleep quality were both related to diurnal cortisol levels in boys, but not in girls. ${ }^{9}$ Further, a recent actigraphy-based cross-sectional study conducted with 55 healthy individuals aged 8-16 years found that increased HPA activity was associated with longer duration of staying awake as well as poorer sleep efficiency and greater number of awakenings. ${ }^{10}$

Further cross-sectional research has been conducted in younger ages, using both objective and subjective sleep measures. In an actigraphy-based study in eight-year-old children $(\mathrm{N}=282)$, shorter average sleep duration and lower sleep efficiency were both associated with higher levels of salivary cortisol. ${ }^{11}$ Another study using sleepelectroencephalography in 113 children aged 6-10 years found that morning cortisol secretion was negatively

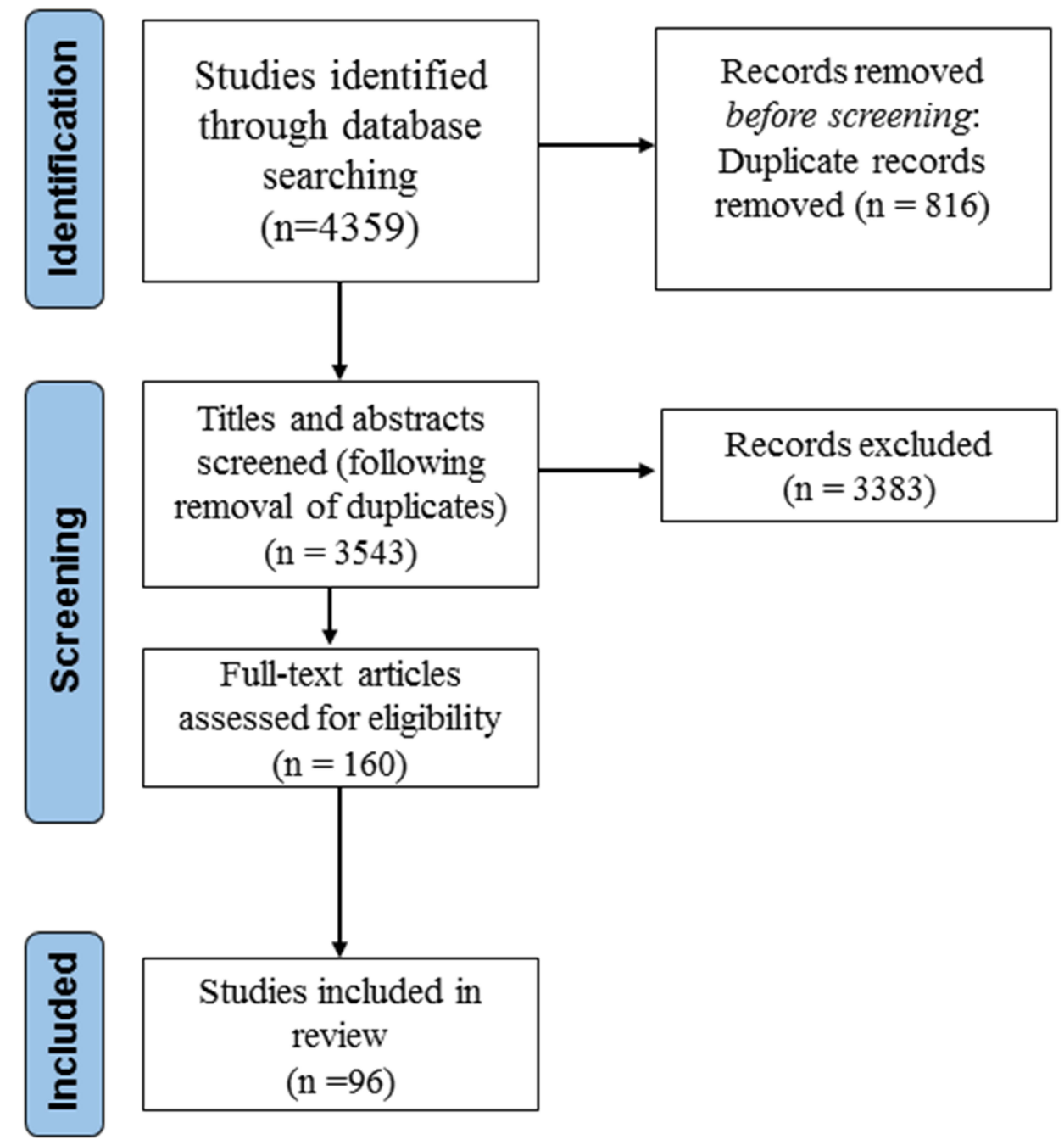

Figure I Flowchart outlining the search and selection strategy. This figure describes the search and selection for strategy for the studies included in this narrative review. Initially, 4359 studies were identified through database searching; then, 3543 studies out of them were screened for titles and abstracts; and out of these 3543 studies, 160 full-text articles were assessed for eligibility. Finally, 96 studies were included in this narrative review. 
associated with sleep duration and slow wave sleep and positively associated with the relative amount of Stage 2 sleep during the preceding night. ${ }^{12}$ Further, El-Sheikh et al reported in a study where they combined actigraphy and self-reported sleep measures in a group of nine-year-old children $(\mathrm{N}=64)$ that higher levels of cortisol were related to increased subjective sleep problems and objective shorter sleep duration and poorer sleep quality. ${ }^{13}$ Pesonen et al $^{14}$ examined 284 eight-year-old children and found that boys with parent-reported sleep problems (eg, difficulties in initiating and maintaining sleep, excessive somnolence, or nightmares) had lower levels of diurnal salivary cortisol. But these findings were unrelated to actual sleep duration measured by actigraphy. Finally, another study combining parent-reported insomnia symptoms with polysomnography-based sleep duration in 327 children aged 5-12 years old showed that parent-reported insomnia with objective short sleep duration was associated with higher cortisol levels. ${ }^{15}$

The existing studies in preschoolers have mainly used objective sleep measures. The first of these studies was done using polysomnography-based sleep recordings in 67 preschool-children aged 5.34 years and showed that the level of cortisol secretion was significantly lower in good sleepers, ${ }^{16}$ while poor sleepers ${ }^{16}$ displayed a significantly increased cortisol secretion. ${ }^{17}$ Another cross-sectional study conducted with 82 preschoolers (mean age $=4.91$ years) using actigraphy showed that children with high cortisol secretion had extended sleep-onset latency and decreased sleep efficiency. ${ }^{18}$

Finally, few longitudinal studies have been conducted in infants and toddlers using parent-reported sleep measures. In a study of 322 infants aged 12-20 months, infants with a flatter diurnal cortisol slope, which is considered maladaptive, and those with a more marked morning cortisol rise had shorter nighttime sleep duration. ${ }^{19}$ Further, a longitudinal study in 51 mothers and their 18-20-monthold toddlers showed that blunted cortisol secretion patterns predicted risk for early emerging sleep problems. ${ }^{20}$

Therefore, the existing evidence suggests that associations between sleep problems and HPA axis dysfunction are evident in young ages, from adolescence to infancy. And this evidence has been supported using both subjective and objective sleep measures. More specifically, it seems that sleep difficulties are associated with increased cortisol levels, and consequently with increased HPA axis activity, in early stages of the development. However, further longitudinal studies are still needed and there is still some inconsistency concerning the associations between objective sleep duration and cortisol levels. In addition, little is known yet about the directionality of these associations. Within the context of the associations between early sleep problems and subsequent BPD symptoms, which is the focus of this review, sleep difficulties in early childhood might increase HPA axis activity, which would consequently lead to BPD symptomatology. However, further specific studies on this topic are required to test this pathway.

\section{Sleep and Prefrontal Cortex}

A number of studies have described abnormal prefrontal cortex in individuals with BPD. ${ }^{21}$ For example, reduced glucose metabolism in the prefrontal cortex has been reported in BPD patients (mean age $=34.2$ years old). ${ }^{22}$ Further, BPD patients (aged 20-43 years old) demonstrated decreased metabolism in anterior cingulate and prefrontal cortex. ${ }^{23}$ In addition, some adolescents with BPD had structural alterations in frontolimbic regions. ${ }^{24}$ Concerning the role that sleep problems may have in the prefrontal cortex, there is evidence that the prefrontal cortex is particularly sensitive to sleep deprivation and benefits from good sleep practices. ${ }^{25}$ However, most of the existing evidence comes from studies in adults with a limited number of studies focusing on young people.

What is the Impact of Sleep on the Prefrontal Cortex in Young Adulthood, Adolescence and Childhood?

A cross-sectional study of 20 young subjects (age range 17-23) using functional magnetic resonance imaging (fMRI) showed that sleep deprivation associated with deficits in the bilateral inferior frontal gyrus, left subthalamic nucleus and left lingual gyrus. ${ }^{24}$ Further, a recent crosssectional study with 25 healthy young adults and adolescents (age range $=12-22$ ) using actigraphy and restingstate fMRI showed that irregular sleep patterns are associated with increased network connectivity in the default mode network- specifically in the right and left lateral parietal lobule. ${ }^{26}$ In adolescents, three studies have examined the associations between sleep and brain structure. In one of these studies using structural MRI, the brain areas in which higher volume was correlated with longer sleep duration included the orbitofrontal cortex, prefrontal and temporal cortex, precuneus, and supramarginal gyrus. ${ }^{27}$ Another cross-sectional study conducted in 177 adolescents (mean age 14.4 years), the medial prefrontal cortex correlated both with bedtime and wake-up times. ${ }^{28} \mathrm{~A}$ third 
study conducted in forty-six adolescents using a functional MRI scan during which they completed a cognitive control and risk taking task found that adolescents who reported poorer sleep also exhibited less recruitment of the dorsolateral prefrontal cortex during cognitive control. ${ }^{29}$

So far, only two studies have examined the associations between sleep and brain areas in children. In a crosssectional study in 15 male children (ages 7-11 years), shorter sleep duration contributed to neural alterations of brain regions involved in the regulation of emotion and reward processing (including prefrontal areas). ${ }^{30} \mathrm{In}$ a longitudinal study from the Generation $\mathrm{R}$ cohort, mothers reported sleep disturbances in 720 children at ages 2 months, 1.5, 2, 3, and 6 years and T1-weighted MRI images were used to assess brain structure at 7 years. The authors reported that more adverse developmental course of childhood sleep disturbances was associated with smaller grey matter volumes and thinner dorsolateral prefrontal cortex. ${ }^{31}$ Therefore, there is still limited research examining the specific effects of sleep in prefrontal brain areas in young ages. Among the existing evidence, the studies support those findings from adult research and suggest that sleep problems have an impact on the prefrontal cortex. However, further studies in this area are still needed and especially longitudinal studies and manipulation studies in young children and infants. The current evidence, and specially the one that comes from sleep deprivation studies, supports the notion that early sleep problems might have an impact in prefrontal areas, and subsequently, impairments at this cortical level might underlie the development of BPD symptoms.

\section{Overlapping Psychosocial Risk Factors for BPD and Sleep}

\section{Sleep and Family Psychopathology}

There is convincing evidence that the families of patients with BPD have greater rates of psychopathology (eg, depressive, substance abuse, or antisocial disorders) than the families of healthy controls. ${ }^{32}$ This may be due to the familial risk and heritability observed in BPD patients ${ }^{33}$ or due to the maladaptive parenting strategies frequently experienced by BPD patients. ${ }^{34}$ Research investigating the links between offspring sleep and parental psychopathology has been limited. Most studies in this area are related to maternal depression, and more specifically in the perinatal and postnatal period. Further, all these studies have mainly focused on the effects of parental mental health on their offspring's sleep during childhood or infancy, and thus for this specific section, we will focus here on these stages.

What is the Association Between Sleep and Family Psychopathology in Early Childhood?

Concerning the effect that parental mental health has in sleep development in early childhood, and in relation to the perinatal period, depressed pregnant women seem to have newborns exhibiting higher levels of disrupted sleep.35 Similarly, prenatal maternal anxiety and depression predict more sleep problems in toddlers aged 18-30 months, ${ }^{36}$ and mothers with prenatal depression report more night awakenings in their one-year-old infants. ${ }^{37}$ There is also evidence that both mother's prenatal and early postpartum depression symptoms associate with the emergence of infant's sleep problems. ${ }^{38}$ With respect to postpartum depression only, depressed mothers report more infants' sleep difficulties in the first weeks, ${ }^{39}$ and in the first year. ${ }^{40}$ Further, maternal report of infant sleep problem can be considered a significant predictor of maternal postnatal depression. ${ }^{41}$ Beyond the infancy period, in a clinical sample of mothers with mood disorders, ${ }^{42}$ sleep problems are more frequent, severe and persistent in infants of depressed mothers. Similarly, maternal symptoms of anxiety and depression during the first year of the child's life are associated with nocturnal awakening at six and 18 months. ${ }^{43}$ Finally, infant sleeping problems relate to maternal depressive (and comorbid anxiety) disorders irrespective of maternal parity. ${ }^{44}$

Among the effects that maternal depression has in toddlers' and/or children's sleep functioning, most evidence supports the negative effect of maternal depression. In a large cross-sectional study using a large representative sample of 2-3 years old children, self-reported mother depressive symptomatology contributed to parent-reported sleep problems in toddlers. ${ }^{45}$ Similarly, in another crosssectional study in 6000+ 3-to-4 years old twin pairs, maternal depression was associated with sleep problems. ${ }^{46}$ Another cross-sectional study conducted in 4-9 years old children ( $\mathrm{N}=1391)$ corroborated the associations between maternal depression and children's sleep disturbances also in preschoolers and school-aged children. ${ }^{47}$ Only one study, so far, has examined the effects of maternal depression in their offspring sleep using polysomnography in 64 healthy infants and showed that altered sleep structure was observed in children born from depressed mothers. ${ }^{48}$ 
Few studies have also examined other maternal mental health problems, rather than maternal depression. Previous research suggests that infant sleep problems are associated with poorer health in both parents. ${ }^{49}$ In a study conducted by Warren et $\mathrm{al}^{50}{ }^{50}$ the authors examined four- and 14month-old infants of mothers with panic disorder (PD) and showed that infants from the four-month cohort with PD mothers had more fragmented sleep at eight months. In another study, in a sample of cocaine-exposed sevenmonth-old infants, ${ }^{51}$ the findings showed that exposed infants who had mothers with higher levels of anxiety showed higher levels of sleep problems. Finally, a recent study reported that several maternal risk factors during pregnancy were related to sleep difficulties in infants. ${ }^{52}$ In relation to children, in a study conducted including 182 families, bedtime behavior and daytime sleepiness seemed to be greatly affected in those children of mothers with mental health problems. ${ }^{53}$

To sum up, the existing literature has been mainly focused on maternal depression, especially perinatal and postnatal depression and mostly in children and infants. Also, most of these studies have been conducted using parent-reported sleep measures and scarce research has used objective-based sleep measures. Further, some attempts have been made to investigate the role of other maternal mental disorders on infants' sleep. The existing evidence suggests that mother mental health problems may lead to subsequent sleep problems in their children, although there is also some evidence suggesting the opposite effect (ie, the impact of sleep on parent's psychopathology). In the context of the development of BPD and the role of sleep, this evidence suggests that parental mental health problems could be a common risk factor for sleep problems and BPD symptoms.

\section{Sleep and Disrupted Attachment}

Problems in secure attachment formation are associated with both BPD psychopathology ${ }^{54}$ and child sleeping problems. ${ }^{55}$ Considering that attachment has been mainly studied in infancy and childhood, the studies reported in this section will cover these stages.

\section{How Do Sleep and Disrupted Attached Interact in Early} Childhood?

In a meta-analysis study conducted in 2017 , the authors reported positive associations between secure infantmother attachment and sleep efficiency and insecure-resistant attachment and sleep problems. ${ }^{56}$ Most of the studies on the topic have been conducted using a longitudinal approach. For instance, in a study using objective measures of sleep and attachment in 62 middle-class families, children with secure attachment subsequently slept more and had higher sleep efficiency than those with insecure attachment. ${ }^{57}$ In another longitudinal study using parentreported sleep measures in 134 mother-child dyads between six and 36 months, ${ }^{58}$ it was shown that children with disorganized attachment had prospectively shorter sleep duration, later bedtime, and more awakenings. In another longitudinal study where attachment at 18 months and children's actigraph-based and parent-reported sleep quality at 24 months were examined in 55 families, ${ }^{59}$ higher resistance predicted longer wake duration at night.

Longitudinal studies in infants have also reported the association between attachment and sleep. ${ }^{60}$ For instance, information on night wakings in 93 infants showed that attachment at 12 months was related to infant night waking patterns in the first six months of life. In another longitudinal study where attachment and sleep were measured from seven to 14 months of child's life, infants with a secure attachment had lower number of night wakings over time. ${ }^{61}$ Further, there is also evidence of the impact of sleep difficulties in subsequent disruption of attachment in early childhood. For instance, infants with insecure-resistant attachments at 15 months have greater numbers of night wakings and longer night-waking episodes at six and 15 months. ${ }^{62}$ Similarly, sleep problems in infants at three months were associated with disorganized attachment at 18 months. $^{63}$

In whole, the existing evidence suggests that disruptive attachment leads to sleep difficulties in infancy and childhood, but there is also evidence that early sleep problems might impact later attachment styles, suggesting a bidirectional association between sleep and attachment. In relation to the associations between early sleep and BPD, one explanation could be that disrupted attachment may be a common risk factor for both sleep problems and BPD. But also, other potential explanation could be that early sleep problems would lead to disrupted attachment, which consequently leads to the development of BPD symptoms. Further longitudinal research on how disrupted attachment, early sleep difficulties and BPD symptoms interact with each other is still needed.

\section{Sleep and Childhood Maltreatment}

BPD associates with history of maltreatment in childhood. ${ }^{64}$ Further, childhood abuse could be also a 
risk factor for sleep difficulties. Although the effects of childhood maltreatment can also lead to sleep problems in adulthood, ${ }^{65}$ for this review, we will only focus on those relevant studies investigating the associations between childhood maltreatment and sleep in childhood, adolescence and young adults.

What is the Impact of Childhood Maltreatment on Sleep in Childhood, Adolescence and Young Adulthood?

In a recent study conducted in 18-22 years old young adults, childhood emotional neglect predicted insomnia symptoms. ${ }^{66}$ Further, in a recent study conducted including 181 college students, those who reported more childhood maltreatment also reported significantly lower quality sleep and felt less rested upon awakening. ${ }^{67}$ In adolescence, a study conducted in 73 subjects found that more severe childhood maltreatment was related to increased sleep disturbances. ${ }^{68}$ In another longitudinal study using 2910 adolescents aged 14-17 years old, sexual abuse, physical abuse, intimate partner violence, emotional maltreatment and physical neglect in childhood were all associated with several sleep problems in adolescence. ${ }^{69}$ Another recent study conducted in 153,547 adolescents found that physical abuse, emotional abuse, sexual abuse, physical neglect or emotional neglect associated with increased risk of sleep disturbance. ${ }^{70}$ In 1997, a study using 44 pre-pubertal children found that abused children had prolonged actigraphy-based sleep latency and decreased sleep efficiency. ${ }^{71}$

In a large population-based sample of adolescents $(\mathrm{N}=$ 9582), youth exposed to childhood adversity were more likely to have insomnia, with a larger risk for those exposed to interpersonal violence during early childhood or adolescence, and a clear dose-response relationship between exposure to multiple types of adversity and risk for insomnia. ${ }^{72}$ Another longitudinal study in 147 female adolescents showed that sexually abused participants reported greater rates of sleep disturbances. ${ }^{73}$ Finally, in a recent longitudinal cohort study of 2491 children at 5-9 and 10-16 years old, having an accumulation of childhood adversities significantly associated with sleep disturbances in youth $10-16$ years, but not in younger children. ${ }^{74}$

Therefore, the existing evidence suggests that childhood maltreatment may lead to sleep difficulties in young adulthood, adolescence and childhood. However, most of this research has been conducted using subjective sleep measures and further research using objective-based sleep measures is needed. Within the context of the associations between early sleep and BPD, childhood maltreatment could be a common risk factor for sleep and BPD symptoms.

\section{Core Features of BPD}

Sleep and Impulsivity

Impulsivity in BPD is a central symptom. ${ }^{75}$ Further, although inadequate sleep has been linked to poor impulse control in adults, little research has investigated the role of sleep on impulsive behaviors in younger ages.

What is the Link Between Sleep and Impulsivity in Young Adulthood, Adolescence and Childhood?

In relation to the associations in young adults, one study conducted in 373 young adults (18-29 years) found that higher levels of sleepiness associated with several types of impulsivity. ${ }^{76}$ Another recent study in 13- to-19-year-olds diagnosed with bipolar disorder (BD; $\mathrm{n}=33,16.2$ years), the change in sleep duration between school days and weekends was associated with increased impulsivity. ${ }^{77}$ Further, one study conducted in 19 young adults showed that acute sleep restriction caused deregulation of cognitive control that may manifest in increased impulsivity. ${ }^{78}$

In children and adolescents, there is also some research on the associations between sleep and impulsivity. In one study conducted in 87 healthy participants (8.6 to 15.8 years) ${ }^{79}$ sleepiness following acute sleep restriction was not sufficient to produce deficits in impulsivity and sustained attention. Further, another study conducted in 1180 children (7-10 years) showed that children with sleep disorders had greater predisposition to impulsivity. ${ }^{80} \mathrm{~A}$ randomized trial using a sample of 34 typically developing children aged 7 to 11 years reported that a cumulative restriction of sleep of 54.04 minutes was associated with detectable deterioration in restless-impulsive behavior scores. ${ }^{81}$

Therefore, the existing scarce evidence from studies in young people and adolescents suggests that sleep might play a causal role in the development of impulsive behaviours, while further research is still needed to confirm whether this is also true in children. However, with the existing evidence we can hypothesize that impulsivity could be considered a mediating factor in the associations between early sleep and BPD symptoms; however, further research is still needed.

\section{Sleep and Emotion Regulation}

Emotion dysregulation is often considered a core characteristic of BPD. ${ }^{82}$ Further, there is also evidence about the 
associations between emotion regulation and sleep, such as the developmental cascade model in which sleep problems have a persistent negative effect on emotional regulation, which in turn contributes to ongoing sleep problems and poorer attentional regulation in children over time. ${ }^{83} \mathrm{In}$ recent years, there has been also an increasing research interest in understanding the bidirectional relationship between emotion and sleep. The relationship between inadequate sleep and mood has been well established in adults. However, further studies are still needed in younger ages, and especially to investigate the potential role of sleep in emotion regulation.

What is the Association Between Sleep and Emotion Regulation in Young Adulthood, Adolescence and Childhood?

In a recent cross-sectional study conducted in young people (20 years old), distraction and reappraisal (ie, two emotion regulation strategies) were impaired by sleep deprivation. ${ }^{84}$ Another sleep deprivation study with 50 healthy adolescents, aged 14-17, confirmed that several nights of sleep restriction adversely affects adolescents' ability to regulate their emotions. ${ }^{85}$ In another manipulation study, but this time in 32 children ( $8-12$ years), modest differences in sleep duration, accumulated over few days, affected critical emotional functions in children.${ }^{85}$ Further, a recent study showed that after two nights of sleep restriction conducted in a sample of 53 children aged 7-11 years old alterations in children's affect, emotional arousal, facial expressions, and emotion regulation appeared. ${ }^{86}$ In young children, in a sleep restriction study conducted in 10 healthy toddlers (30-36 months), ${ }^{87}$ sleep restriction resulted in an increase in negative emotional responses.

This relationship between sleep and emotion regulation has been also tested in large representative samples of adolescents. For instance, in a nationally representative sample ( $\mathrm{N}=10,148 ; 13-18$ years), differential relations between sleep problems and certain regulation strategies were found. ${ }^{88}$ Finally, some attempts have been conducted to specifically investigate the role of sleep problems and emotion regulation in BPD. In a study conducted in 450 undergraduates (23 years old), BPD characteristics capturing emotional dysregulation showed the strongest correlations with poor sleep quality. ${ }^{89}$ Further, a recent study conducted in 217 adolescent inpatients with self-reported measures of sleep disturbance, emotional dysregulation and BPD symptoms showed that BPD features and emotion dysregulation were significantly related to indices of sleep disturbance, but there was no empirical support for the mediating role of emotion regulation in the relation between sleep and BPD. ${ }^{90}$ Also in relation to sleep problems and emotion regulation in BPD, one study examined the level of dream disturbances (ie, nightmares) in connection with measures of emotional instability in 23 subjects diagnosed with BPD and 23 controls, and found an association between dream disturbances and levels of emotional instability in BPD patients. ${ }^{91}$

Therefore, the existing evidence supports the notion that sleep problems might have a role in the development of emotional dysregulation. In relation to the topic of this review, sleep problems in early childhood might lead to emotional dysregulation, which subsequently would lead to BPD symptoms. Therefore, emotional dysregulation could be treated as a mediating factor in the associations between early sleep and subsequent BPD. However, the potential mediation role of emotion dysregulation in the association between sleep and BPD should be further investigated, preferably using longitudinal approaches for large sample size of individuals.

\section{Sleep and Internalizing/Externalizing Problems}

BPD is highly comorbid with internalizing and externalizing psychopathology. ${ }^{92}$ Concerning sleep in childhood, one common finding is the links with internalizing and externalizing difficulties. Some studies have focused on internalizing and externalizing problems separately, while others have included both constructs together.

\section{How Do Sleep and Internalizing/Externalizing Symptoms} Associate in Adolescence and Childhood?

Concerning the associations between sleep and internalizing problems, in a study in 300 eight-year-old twin pairs, several sleep difficulties were associated with depression, and the overall association was largely influenced by genes. ${ }^{93}$ Following the research on the genetic contribution, a recent study conducted with 5111 adolescent twin pairs reported also a large genetic overlap between sleep problems and internalizing symptoms. ${ }^{94}$ Some other studies have focused on the prospective associations between sleep and internalizing symptoms. In a recent longitudinal study among 319 youth (aged 11-26 years), dysregulated sleep was bidirectionally associated with clinician-rated anxiety and depression symptom severity. ${ }^{95}$ In another recent study in 993 and 736 participants (longitudinal cohort entry age of 10/11 years), sleep duration was not 
longitudinally associated with internalizing problems but it was in the cross-sectional analyses. ${ }^{96}$ Further, a longitudinal study conducted in 2,510 adolescents reported the effect of sleep duration and cigarette smoking on later internalizing problems. ${ }^{97}$ Another longitudinal study conducted in 1,089 children found that bedtime but not nighttime waking problems significantly predicted adolescent internalizing problems. ${ }^{98}$ In younger ages, a recent longitudinal study conducted in 35,075 mothers of children between 1.5 and 8 years old showed a bidirectional association between subjective sleep and internalizing symptoms from toddlerhood to middle childhood. ${ }^{99}$ Further, and using actigraphy measures, a recent study conducted in 119 children assessed longitudinally at 30, 36, 42, and 54 months reported that sleep variability and late sleep timing in toddlerhood were associated with higher levels of internalizing problems. ${ }^{100}$

Regarding the research on the associations between sleep and externalizing problems, in a longitudinal study by Muratori et al in 227 children (6-10 years), ${ }^{101}$ increased sleep problems associated with worsening of inattentive and hyperactive behavioral problems one year later. Similarly, in a cross-sectional study in 8950 preschoolers, shorter nighttime sleep duration was associated with higher likelihood of parent-reported externalizing symptoms. ${ }^{102}$ Also in preschoolers, a study of 510 children aged 2 to 5 years reported that parent-reported short sleep was associated with more externalizing problems. ${ }^{103}$ Further, in a recent study conducted in 196 children aged 34-77 months externalizing problems rather than cognitive development were associated with sleep difficulties in preschool children with developmental disability. ${ }^{104}$

Most of the studies on the topic have examined the effects of sleep with both internalizing and externalizing symptoms. In adolescents, in a longitudinal study in 555 young adolescents (Mean age $=13.96$ ), sleep problems were precursors of substance use, internalizing and externalizing problems in adolescence. ${ }^{105}$ Concerning studies in childhood, in a cohort study using data obtained every 2 years in 4983 children aged 4-5 years, bidirectional associations were found between sleep problems and externalizing but not with internalizing symptoms. ${ }^{106}$ Further, in a longitudinal study including 270 children with ADHD, aged 5-13 years, the main findings showed a weak evidence of a bidirectional relationship between sleep problems and internalizing/externalizing problems. ${ }^{107}$

In younger children, in a study conducted in 297 families with 5-6-year-old preschoolers, both short sleep duration and sleeping difficulties were associated with children's behavioral symptoms. ${ }^{108}$ Childhood sleep problems have also been related to maternal ratings of internalizing and externalizing problems during adolescence for both boys and girls in a study with 292 boys and 94 girls from a community sample of high-risk families. ${ }^{109}$ Further, a recent study conducted in 48 boys and 74 girls aged 7-11 years reported that parental reports of sleep disturbances can be used to identify children at increased risk for internalizing and externalizing problems. ${ }^{110}$ Another study conducted in a sample of 285 elementary school students found that self-reported time in bed and sleep quality was negatively associated with internalizing and externalizing symptoms. ${ }^{111}$ In a recent longitudinal study, Williamson et al examined 4517 children recruited at birth and found that children with increased middle childhood sleep problems experienced greater internalizing and externalizing symptoms at 10-11 years. ${ }^{112}$

Also, in a recent longitudinal study with more than 1000 infants and toddlers, ${ }^{113}$ short sleep duration and more night wakings in infancy were associated with internalizing symptoms at 24 months; and more night wakings and longer sleep-onset latency in infancy with externalizing problems at 24 months. Another study in 123 toddlers reported that short sleep predicted greater externalizing behaviors a year later. ${ }^{114}$ In a 2017 study, later bedtimes and less total sleep predicted social-emotional problems in infants and toddlers. ${ }^{115}$ A larger longitudinal study conducted in 32,662 children reported that short sleep duration and frequent nocturnal awakenings at 18 months significantly predicted both concurrent and later incidence of emotional and behavioral problems at 5 years. ${ }^{116}$ In a cross-sectional study among a community sample of children and adolescents $(\mathrm{N}=175)$, depressive symptoms showed a greater association with sleep problems among adolescents, while anxiety symptoms were generally associated with sleep problems in all youth. ${ }^{117}$ Similarly, a longitudinal study in 1001 toddlers from 24- to 36-months found specific relations between sleep problems and internalizing and externalizing problems during toddlerhood. ${ }^{118}$

To sum up, these findings suggest that there is a robust association between sleep problems and both internalizing and externalizing problems at different stages from infancy to young adulthood. Several studies suggest the existence of a bidirectional association, but more evidence supports the notion that sleep affects internalizing/externalizing symptoms, rather than the opposite direction. However, further research is still needed. In the context of this 
review, we suggest that early sleep problems might underlie the development of internalizing/externalizing problems which subsequently may lead to BPD symptoms. However, another approach could be that internalizing/ externalizing symptoms are a common factor of sleep and BPD symptoms, thus further investigation is required.

Table 1 describes the key features of each of the studies included in this narrative review.

\section{Conclusion}

There are several pathways that could explain why sleep problems and subsequent BPD symptoms associate (see Figure 2). In this review, we used the biosocial developmental model of BPD as a framework to discuss how sleep problems might associate with the development of BPD including some of the correlates, risk and/or etiological factors described in this model. For instance, here we present evidence that supports the link between early sleep and some of the most relevant features that characterize BPD (ie, dysfunction of the HPA axis and prefrontal cortex, family psychopathology, disrupted attachment, childhood maltreatment, impulsivity, emotion regulation, and internalizing/externalizing symptoms). Therefore, this suggests that some of these factors could act as mediating factors in the associations between sleep and subsequent BPD symptoms (ie, HPA, prefrontal functioning, emotional dysregulation, impulsivity and internalizing/externalizing symptoms), while some other factors might constitute a common risk factor (ie, family psychopathology, disrupted attachment and childhood maltreatment). Other potential explanations using the biosocial developmental model of BPD could relate to the fact that early sleep problems could be an indicator of early difficulties with regulation, which in turn would predict higher levels of co-developing internalizing and externalizing symptoms which subsequently lead to the development of BPD psychopathology in adolescence. ${ }^{119}$ In addition, there is some evidence which suggests that sleep disturbance might play a causal role in some of these processes. To ascertain this causal role of sleep, experimental designs such as sleep manipulation are required. ${ }^{120}$ For instance, there is evidence for a causal link between sleep deprivation and deficits at the level of the prefrontal cortex, as well as increased impulsivity and/or dysregulation problems, using cross-sectional studies. Further, longitudinal studies partially support the fact that early sleep problems might potentially cause disruptions in the development of secure infant-mother attachment and externalizing and internalizing symptoms in childhood. These studies report that sleep problems precede the development of subsequent child and family-related difficulties, and although longitudinal designs cannot fully determine causality, their analyses meet some of the Bradford Hill criteria for causation, such as temporality and plausibility. ${ }^{121}$ However, there is still a lack of studies investigating the potential mechanisms by which sleep disturbances might lead to some of these processes. There is a need for further research on the potential underlying mechanisms such as family factors, parenting strategies, or biochemical changes in the central nervous system.

A strength of the literature included in this review is the inclusion of a variety of processes potentially associated with sleep and which could explain the link between sleep and BPD. Therefore, this provides evidence of a number of potential mechanisms underlying these associations and allows us to advance on the current knowledge of the topic. Further, to do so, this narrative review uses as a framework the biosocial development model of BPD, which is a well-tested model of BPD. Other strength of this narrative review is the inclusion of both subjective and objective sleep measures. Further, we also included not only cross-sectional studies but also longitudinal and sleep manipulation studies, which allows to decipher the potential causal role of sleep in some of these processes. However, we only focused here on some of the processes presented in the biosocial development model of BPD, while some other potentially relevant mechanisms are not discussed in this narrative review, which constituted a disadvantage of the present work. Further, other limitations of the current review of the literature are (i) the small sample size used in some of the studies; (ii) many of the studies were cross-sectional and thus causality cannot be inferred; and (iii) a relatively short follow-up period in most of the longitudinal studies included. In addition, due to the nature of the current review (ie, narrative review), this was limited by the subjective nature of its methodology, rather than presenting the operationalization of the variables, the magnitude of effect sizes, and/or the sample sizes, which is characteristic of a systematic review. Further, we only included two databases as search engines and there was no critical appraisal of the included studies. Future studies should consider conducting a systematic review and/or meta-analysis to reveal patterns in the current literature that could not be detected through a narrative review. 
Table I Description of the Studies Included in the Narrative Review

\begin{tabular}{|c|c|c|c|c|c|c|}
\hline & \multirow{2}{*}{$\begin{array}{l}\text { Study } \\
\text { Design }\end{array}$} & \multirow[t]{2}{*}{$\mathbf{N}$} & \multirow{2}{*}{$\begin{array}{l}\text { Age/Age } \\
\text { Grouping }\end{array}$} & \multicolumn{2}{|c|}{ Sleep Measure } & \multirow[t]{2}{*}{ Main Findings } \\
\hline & & & & Objective & Subjective & \\
\hline \multicolumn{7}{|l|}{$\begin{array}{l}\text { Sleep and } \\
\text { HPA }\end{array}$} \\
\hline $\begin{array}{l}\text { El-Sheikh } \\
\text { et al }(2008)^{13}\end{array}$ & $\begin{array}{l}\text { Cross- } \\
\text { sectional }\end{array}$ & 64 & $\begin{array}{l}\text { Mean }=8.75 \\
\text { years } \\
\text { Age grouping: } \\
\text { childhood. }\end{array}$ & $\begin{array}{l}\text { Actigraphy: total sleep } \\
\text { minutes, sleep efficiency, } \\
\text { minutes awake after sleep } \\
\text { onset, and sleep activity }\end{array}$ & $\begin{array}{l}\text { The Sleep Habits Survey: } \\
\text { sleepiness and sleep/wake } \\
\text { problems. }\end{array}$ & $\begin{array}{l}\text { Cortisol measure: children came } \\
\text { to the laboratory to provide saliva } \\
\text { samples, which were used to } \\
\text { assess cortisol. } \\
\text { There was a significant } \\
\text { relationship between higher levels } \\
\text { of cortisol and increased } \\
\text { subjective sleep problems, poorer } \\
\text { sleep quality and shorter sleep } \\
\text { duration. }\end{array}$ \\
\hline $\begin{array}{l}\text { Fernandez- } \\
\text { Mendoza } \\
\text { et al }(2014)^{15}\end{array}$ & $\begin{array}{l}\text { Cross- } \\
\text { sectional }\end{array}$ & 327 & $\begin{array}{l}\text { Range=5-12 } \\
\text { years } \\
\text { Age grouping: } \\
\text { childhood. }\end{array}$ & $\begin{array}{l}\text { Polysomnography: sleep } \\
\text { duration }\end{array}$ & $\begin{array}{l}\text { Pediatric Behavior Scale: insomnia } \\
\text { symptoms of difficulty initiating } \\
\text { and/or maintaining sleep. }\end{array}$ & $\begin{array}{l}\text { Cortisol measure: children } \\
\text { provided evening and morning } \\
\text { saliva samples to assay for } \\
\text { cortisol. } \\
\text { There was a significant association } \\
\text { between parent-reported } \\
\text { insomnia symptoms with } \\
\text { objective sleep duration and } \\
\text { higher cortisol levels in the } \\
\text { evening and morning. }\end{array}$ \\
\hline $\begin{array}{l}\text { Hatzinger } \\
\text { et al }(2008)^{17}\end{array}$ & $\begin{array}{l}\text { Cross- } \\
\text { sectional }\end{array}$ & 67 & $\begin{array}{l}\text { Mean=4.91 } \\
\text { years } \\
\text { Age grouping: } \\
\text { childhood. }\end{array}$ & $\begin{array}{l}\text { Polysomnography: REM } \\
\text { sleep time, number of } \\
\text { awakenings after sleep } \\
\text { onset, and sleep efficiency }\end{array}$ & $\mathrm{N} / \mathrm{A}$ & $\begin{array}{l}\text { Cortisol measure: for baseline } \\
\text { HPA-activity assessment, saliva } \\
\text { samples were collected } \\
\text { immediately after awakening, } \\
\text { whereas saliva samples before, } \\
\text { while and after a psychological } \\
\text { challenge were used to assess the } \\
\text { HPA-activity under stress } \\
\text { conditions. } \\
\text { "Poor" sleepers showed } \\
\text { significantly increased morning } \\
\text { cortisol levels. } \\
\text { An elevated number of } \\
\text { awakenings after sleep onset were } \\
\text { significantly associated with } \\
\text { increased cortisol levels under } \\
\text { stress conditions. }\end{array}$ \\
\hline $\begin{array}{l}\text { Hatzinger } \\
\text { et al }(2010)^{18}\end{array}$ & $\begin{array}{l}\text { Cross- } \\
\text { sectional }\end{array}$ & 82 & $\begin{array}{l}\text { Mean=4.91 } \\
\text { years } \\
\text { Age grouping: } \\
\text { childhood. }\end{array}$ & $\begin{array}{l}\text { Actigraphy: sleep onset } \\
\text { latency, awakening time, } \\
\text { number and times of } \\
\text { awakenings after sleep } \\
\text { onset, sleep period time } \\
\text { and sleep efficiency }\end{array}$ & $\begin{array}{l}\text { Daily log of their child's sleep: } \\
\text { bedtime, wake-up time, sleep } \\
\text { duration, awakenings. }\end{array}$ & $\begin{array}{l}\text { Cortisol measure: on the first and } \\
\text { on the last morning of sleep } \\
\text { registration, the activity of the } \\
\text { HPA axis was assessed via the } \\
\text { amount of cortisol in the saliva. } \\
\text { Children who have poor sleep } \\
\text { patterns with high HPA activity } \\
\text { showed extended sleep onset } \\
\text { latency and sleep efficiency. }\end{array}$ \\
\hline $\begin{array}{l}\text { Kiel et al } \\
(2015)^{20}\end{array}$ & Longitudinal & 51 & $\begin{array}{l}\text { Mean=18.96 } \\
\text { months } \\
\text { Age grouping: } \\
\text { toddlers. }\end{array}$ & $\mathrm{N} / \mathrm{A}$ & $\begin{array}{l}\text { Infant-Toddler Social and } \\
\text { Emotional Assessment: Sleep } \\
\text { scale ( } 5 \text { items). }\end{array}$ & $\begin{array}{l}\text { Cortisol measure: Mothers were } \\
\text { trained by laboratory staff to } \\
\text { gather saliva from their toddlers } \\
\text { using a cotton dental roll. } \\
\text { High morning levels of cortisol } \\
\text { predicted increasing sleep } \\
\text { problems from age } 2 \text { to age } 3 \text {. }\end{array}$ \\
\hline
\end{tabular}

(Continued) 
Table I (Continued).

\begin{tabular}{|c|c|c|c|c|c|c|}
\hline & \multirow{2}{*}{$\begin{array}{l}\text { Study } \\
\text { Design }\end{array}$} & \multirow[t]{2}{*}{$\mathbf{N}$} & \multirow{2}{*}{$\begin{array}{l}\text { Age/Age } \\
\text { Grouping }\end{array}$} & \multicolumn{2}{|c|}{ Sleep Measure } & \multirow[t]{2}{*}{ Main Findings } \\
\hline & & & & Objective & Subjective & \\
\hline $\begin{array}{l}\text { LaVoy et al } \\
(2020)^{10}\end{array}$ & $\begin{array}{l}\text { Cross- } \\
\text { sectional }\end{array}$ & 55 & $\begin{array}{l}\text { Range }=8-16 \\
\text { years } \\
\text { Age grouping: } \\
\text { adolescence. }\end{array}$ & $\begin{array}{l}\text { Actigraphy: minutes awake, } \\
\text { sleep efficiency, sleep } \\
\text { duration, sleep onset } \\
\text { latency and night } \\
\text { awakenings }\end{array}$ & $\begin{array}{l}\text { Sleep diaries, The School Habits } \\
\text { Survey; sleep duration, night } \\
\text { awakenings, wake-up and bedtime, } \\
\text { sleepiness and sleep/wake } \\
\text { behaviour problems. }\end{array}$ & $\begin{array}{l}\text { Cortisol measure: participants } \\
\text { donated first waking saliva } \\
\text { samples, which were later assayed } \\
\text { for } \alpha \text {-amylase (sAA), cortisol, } \\
\text { interleukin (IL)-6, and IL-I } \beta \text {. } \\
\text { Morning cortisol levels were } \\
\text { associated with objective sleep } \\
\text { variables such as sleep efficiency, } \\
\text { minutes spent awake the night } \\
\text { before and night awakening the } \\
\text { night after. }\end{array}$ \\
\hline $\begin{array}{l}\text { Lemola et al } \\
(2015)^{12}\end{array}$ & $\begin{array}{l}\text { Cross- } \\
\text { sectional }\end{array}$ & 113 & $\begin{array}{l}\text { Mean=8.3 years } \\
\text { Age grouping: } \\
\text { childhood. }\end{array}$ & $\begin{array}{l}\text { Sleep- } \\
\text { electroencephalography: } \\
\text { sleep duration, sleep } \\
\text { continuity, and sleep } \\
\text { architecture. }\end{array}$ & N/A & $\begin{array}{l}\text { Cortisol measure: The parents of } \\
\text { the children were instructed to } \\
\text { collect four saliva samples on the } \\
\text { following morning, with the first } \\
\text { one after awakening and } 10,20 \text {, } \\
\text { and } 30 \text { minutes later. } \\
\text { Cortisol secretion was negatively } \\
\text { associated with sleep duration in } \\
\text { school age children and slow wave } \\
\text { sleep and positively associated } \\
\text { with the stage } 2 \text { sleep during the } \\
\text { preceding night. }\end{array}$ \\
\hline $\begin{array}{l}\text { Pesonen et al } \\
(2012)^{14}\end{array}$ & $\begin{array}{l}\text { Cross- } \\
\text { sectional }\end{array}$ & 248 & $\begin{array}{l}\text { Mean=8.I years } \\
\text { Age grouping: } \\
\text { childhood. }\end{array}$ & Actigraphy: sleep duration. & $\begin{array}{l}\text { Sleep Disturbance Scale for } \\
\text { Children: sleep-wake transition, } \\
\text { arousal, excessive daytime } \\
\text { somnolence, sleep hyperhidrosis. }\end{array}$ & $\begin{array}{l}\text { Cortisol measure: salivary } \\
\text { cortisol was sampled throughout } \\
\text { one day at home and during the } \\
\text { Trier Social Stress Test for } \\
\text { Children (TSST-C) in clinic. } \\
\text { Boys with parent-reported sleep } \\
\text { problems had lower levels of } \\
\text { diurnal salivary cortisol levels. } \\
\text { Girls with sleep problems had } \\
\text { unaltered diurnal salivary cortisol. }\end{array}$ \\
\hline $\begin{array}{l}\text { Pesonen et al } \\
(2014)^{9}\end{array}$ & Longitudinal & 305 & $\begin{array}{l}\text { Mean }=123 \\
\text { years } \\
\text { Age grouping= } \\
\text { Adolescence }\end{array}$ & $\begin{array}{l}\text { Actigraphy: sleep duration, } \\
\text { awakening times, } \\
\text { temporary pauses in } \\
\text { actigraph registration, sleep } \\
\text { quality or quantity. }\end{array}$ & $\mathrm{N} / \mathrm{A}$ & $\begin{array}{l}\text { Cortisol measure: Saliva was } \\
\text { obtained during a 2-day period at } \\
\text { awakening and 15, 30, } 45,60 \\
\text { minutes after awakening, at 12:00, } \\
\text { at 17:00 and at bedtime. } \\
\text { Long sleep duration in boys } \\
\text { associated with higher cortisol } \\
\text { awakening response (CAR). } \\
\text { Lower sleep quality in boys was } \\
\text { associated with lower CAR. } \\
\text { In girls, no significant associations } \\
\text { were found. }\end{array}$ \\
\hline
\end{tabular}

(Continued) 
Table I (Continued).

\begin{tabular}{|c|c|c|c|c|c|c|}
\hline & \multirow{2}{*}{$\begin{array}{l}\text { Study } \\
\text { Design }\end{array}$} & \multirow[t]{2}{*}{$\mathbf{N}$} & \multirow{2}{*}{$\begin{array}{l}\text { Age/Age } \\
\text { Grouping }\end{array}$} & \multicolumn{2}{|c|}{ Sleep Measure } & \multirow[t]{2}{*}{ Main Findings } \\
\hline & & & & Objective & Subjective & \\
\hline $\begin{array}{l}\text { Räikkönen } \\
\text { et al }(2010)^{11}\end{array}$ & $\begin{array}{l}\text { Cross- } \\
\text { sectional }\end{array}$ & 282 & $\begin{array}{l}\text { Age }=8 \text { years } \\
\text { Age grouping: } \\
\text { childhood. }\end{array}$ & $\begin{array}{l}\text { Actigraphy: sleep duration } \\
\text { and efficiency }\end{array}$ & $\begin{array}{l}\text { Sleep log: bed and awakening } \\
\text { times. }\end{array}$ & $\begin{array}{l}\text { Cortisol measure: diurnal salivary } \\
\text { cortisol and salivary cortisol and } \\
\alpha \text {-amylase (a sympatho-adrenal- } \\
\text { medullary system marker) } \\
\text { responses to the Trier Social } \\
\text { Stress Test for Children (TSST-C) } \\
\text { were measured. } \\
\text { Children with short average sleep } \\
\text { duration displayed higher salivary } \\
\text { cortisol awakening response. } \\
\text { Children with low sleep efficiency } \\
\text { displayed higher diurnal cortisol } \\
\text { levels. }\end{array}$ \\
\hline $\begin{array}{l}\text { Saridjan et al } \\
(2017)^{19}\end{array}$ & Longitudinal & 322 & $\begin{array}{l}\text { Range }=12-20 \\
\text { months } \\
\text { Age grouping: } \\
\text { infancy/ } \\
\text { toddlers. }\end{array}$ & N/A & $\begin{array}{l}\text { Parental report, Child Behavior } \\
\text { Checklist: Sleep duration and } \\
\text { sleep behaviour. }\end{array}$ & $\begin{array}{l}\text { Cortisol measure: the diurnal } \\
\text { cortisol rhythm was determined } \\
\text { by calculating the area under the } \\
\text { curve (AUC), the cortisol } \\
\text { awakening response (CAR), and } \\
\text { the diurnal slope. } \\
\text { Infants with a flatter cortisol slope } \\
\text { and those with a more marked } \\
\text { morning cortisol rise had shorter } \\
\text { nighttime sleep duration. }\end{array}$ \\
\hline $\begin{array}{l}\text { Zeiders et al } \\
(2011)^{8}\end{array}$ & $\begin{array}{l}\text { Cross- } \\
\text { sectional }\end{array}$ & 119 & $\begin{array}{l}\text { Mean }=19.01 \\
\text { years } \\
\text { Age grouping: } \\
\text { young adults. }\end{array}$ & $\begin{array}{l}\text { Actigraphy: hours of sleep } \\
\text { and wake times }\end{array}$ & $\begin{array}{l}\text { Sleep diary: hours of sleep and } \\
\text { wake times. }\end{array}$ & $\begin{array}{l}\text { Cortisol measure: participants } \\
\text { provided six cortisol samples } \\
\text { (wake-up, }+30 \text { minutes, }+2 \text { hours, } \\
+8 \text { hours, }+12 \text { hours, and } \\
\text { bedtime) on each of three } \\
\text { consecutive days while wearing an } \\
\text { actigraph. } \\
\text { The hours of sleep of the } \\
\text { previous night predicted steeper } \\
\text { diurnal slopes the next day. } \\
\text { Greater waking cortisol levels and } \\
\text { steeper slopes predicted more } \\
\text { hours of sleep and a later wake } \\
\text { time the next day. }\end{array}$ \\
\hline \multicolumn{7}{|c|}{ Sleep and Prefrontal Cortex } \\
\hline $\begin{array}{l}\text { Cheng et al } \\
(2020)^{27}\end{array}$ & $\begin{array}{l}\text { Cross- } \\
\text { sectional }\end{array}$ & 11,067 & $\begin{array}{l}\text { Range=9-1I } \\
\text { years } \\
\text { Age grouping: } \\
\text { childhood. }\end{array}$ & N/A & $\begin{array}{l}\text { Parent Sleep Disturbance Scale } \\
\text { for Children: sleep duration. }\end{array}$ & $\begin{array}{l}\text { Higher volume in orbitofrontal } \\
\text { cortex, prefrontal and temporal } \\
\text { cortex, precuneus and } \\
\text { supramarginal gyrus was } \\
\text { correlated with longer sleep } \\
\text { duration. }\end{array}$ \\
\hline $\begin{array}{l}\text { Kocevska } \\
\text { et al }(2017)^{31}\end{array}$ & Longitudinal & 720 & $\begin{array}{l}\text { From } 2 \text { months } \\
\text { old until } 7 \\
\text { years. } \\
\text { Age grouping: } \\
\text { From } \\
\text { toddlerhood } \\
\text { until childhood }\end{array}$ & N/A & $\begin{array}{l}\text { Parental reports of postal } \\
\text { questionnaires, parental reports } \\
\text { of the Child Behavior Checklist: } \\
\text { sleep disturbance. }\end{array}$ & $\begin{array}{l}\text { Sleep disturbances from age } 2 \\
\text { onwards were associated with } \\
\text { smaller grey matter volumes and } \\
\text { thinner dorsolateral prefrontal } \\
\text { cortex. }\end{array}$ \\
\hline
\end{tabular}

(Continued) 
Table I (Continued).

\begin{tabular}{|c|c|c|c|c|c|c|}
\hline & \multirow{2}{*}{$\begin{array}{l}\text { Study } \\
\text { Design }\end{array}$} & \multirow[t]{2}{*}{$\mathbf{N}$} & \multirow{2}{*}{$\begin{array}{l}\text { Age/Age } \\
\text { Grouping }\end{array}$} & \multicolumn{2}{|c|}{ Sleep Measure } & \multirow[t]{2}{*}{ Main Findings } \\
\hline & & & & Objective & Subjective & \\
\hline $\begin{array}{l}\text { Lunsford- } \\
\text { Avery et al } \\
(2020)^{26}\end{array}$ & $\begin{array}{l}\text { Cross- } \\
\text { sectional }\end{array}$ & 25 & $\begin{array}{l}\text { Mean=18.08 } \\
\text { years } \\
\text { Age grouping: } \\
\text { young adults. }\end{array}$ & Actigraphy: Sleep regularity & N/A & $\begin{array}{l}\text { Irregular sleep patterns were } \\
\text { significantly associated with } \\
\text { increased path length within the } \\
\text { default mode network, specifically } \\
\text { in the right and left lateral parietal } \\
\text { lobule. }\end{array}$ \\
\hline $\begin{array}{l}\text { Reidy et al } \\
(2016)^{30}\end{array}$ & $\begin{array}{l}\text { Cross- } \\
\text { sectional }\end{array}$ & 15 & $\begin{array}{l}\text { Range=7-II } \\
\text { years } \\
\text { Age grouping: } \\
\text { childhood. }\end{array}$ & $\mathrm{N} / \mathrm{A}$ & $\begin{array}{l}\text { Parental report of child's sleep } \\
\text { duration. }\end{array}$ & $\begin{array}{l}\text { Sleep duration linked positively to } \\
\text { amygdala-prefrontal functional } \\
\text { connectivity. }\end{array}$ \\
\hline $\begin{array}{l}\text { Telzer et al } \\
(2013)^{29}\end{array}$ & $\begin{array}{l}\text { Cross- } \\
\text { sectional }\end{array}$ & 46 & $\begin{array}{l}\text { Mean=15.23 } \\
\text { Age grouping: } \\
\text { Adolescence. }\end{array}$ & $\mathrm{N} / \mathrm{A}$ & $\begin{array}{l}\text { Pittsburgh Sleep Quality Index: } \\
\text { poor sleep quality. }\end{array}$ & $\begin{array}{l}\text { Adolescents showed less } \\
\text { dorsolateral prefrontal cortex } \\
\text { (DLPFC) activation during } \\
\text { cognitive control, greater insula } \\
\text { activation during reward } \\
\text { processing, and reduced } \\
\text { functional coupling between the } \\
\text { DLPFC and affective regions. }\end{array}$ \\
\hline $\begin{array}{l}\text { Urrila et al } \\
(2017)^{28}\end{array}$ & $\begin{array}{l}\text { Cross- } \\
\text { sectional }\end{array}$ & 177 & $\begin{array}{l}\text { Mean=14.4 } \\
\text { years } \\
\text { Age grouping: } \\
\text { adolescence. }\end{array}$ & fMRI & $\begin{array}{l}\text { Adolescents report on habitual } \\
\text { bedtimes and wake-up times. }\end{array}$ & $\begin{array}{l}\text { The medial prefrontal cortex was } \\
\text { significantly associated both with } \\
\text { bedtime and wake-up times } \\
\text { during weekends, also with poor } \\
\text { school performance. }\end{array}$ \\
\hline \multicolumn{7}{|c|}{ Sleep and Family Psychopathology } \\
\hline $\begin{array}{l}\text { Bat-Pitault } \\
\text { et al }(2017)^{48}\end{array}$ & $\begin{array}{l}\text { Cross- } \\
\text { sectional }\end{array}$ & 64 & $\begin{array}{l}\text { Age }=<37 \\
\text { weeks } \\
\text { Age grouping: } \\
\text { infancy. }\end{array}$ & $\begin{array}{l}\text { Polysomnography: Sleep } \\
\text { macro-structural } \\
\text { parameters }\end{array}$ & $\mathrm{N} / \mathrm{A}$ & $\begin{array}{l}\text { Maternal psychopathology } \\
\text { measurement: being born to } \\
\text { mothers diagnosed with } \\
\text { depression. } \\
\text { Altered sleep structure was } \\
\text { observed during the first months } \\
\text { of life in infants born from } \\
\text { depressed mothers. }\end{array}$ \\
\hline $\begin{array}{l}\text { Dennis \& } \\
\text { Ross } \\
(2005)^{39}\end{array}$ & Longitudinal & 505 & $\begin{array}{l}\text { Age }= \\
\text { Newborns } \\
\text { Age grouping: } \\
\text { infancy. }\end{array}$ & $\mathrm{N} / \mathrm{A}$ & $\begin{array}{l}\text { Maternal report of infant's sleep } \\
\text { patterns: number of night } \\
\text { awakenings, sleep duration, sleep } \\
\text { quality, and enough sleep. }\end{array}$ & $\begin{array}{l}\text { Maternal psychopathology } \\
\text { measurement: Edinburgh } \\
\text { Postnatal Depression Scale. } \\
\text { Infant sleep patterns and maternal } \\
\text { fatigue were strongly associated } \\
\text { with a new set of depressive } \\
\text { symptoms in the postpartum } \\
\text { period. }\end{array}$ \\
\hline $\begin{array}{l}\text { Dias \& } \\
\text { Figueiredo } \\
(2020)^{38}\end{array}$ & Longitudinal & 164 & $\begin{array}{l}\text { Age }= \\
\text { Newborns } \\
\text { Age grouping: } \\
\text { infancy. }\end{array}$ & $\mathrm{N} / \mathrm{A}$ & $\begin{array}{l}\text { Children's Sleep Habits } \\
\text { Questionnaire: sleep anxiety, } \\
\text { daytime sleepiness and bedtime } \\
\text { resistance. }\end{array}$ & $\begin{array}{l}\text { Maternal psychopathology } \\
\text { measurement: Edinburgh } \\
\text { Postnatal Depression Scale. } \\
\text { Both mother's prenatal and } \\
\text { postpartum depression symptoms } \\
\text { predicted infant's sleep difficulties. }\end{array}$ \\
\hline
\end{tabular}

(Continued) 
Table I (Continued).

\begin{tabular}{|c|c|c|c|c|c|c|}
\hline & \multirow{2}{*}{$\begin{array}{l}\text { Study } \\
\text { Design }\end{array}$} & \multirow[t]{2}{*}{$\mathbf{N}$} & \multirow{2}{*}{$\begin{array}{l}\text { Age/Age } \\
\text { Grouping }\end{array}$} & \multicolumn{2}{|c|}{ Sleep Measure } & \multirow[t]{2}{*}{ Main Findings } \\
\hline & & & & Objective & Subjective & \\
\hline $\begin{array}{l}\text { Field et al } \\
(2007)^{35}\end{array}$ & Longitudinal & 253 & $\begin{array}{l}\text { Age= } \\
\text { Newborns } \\
\text { Age grouping: } \\
\text { infancy. }\end{array}$ & N/A & $\begin{array}{l}\text { Sleep scale: quiet sleep (no REM), } \\
\text { active sleep (without REM), REM } \\
\text { sleep, drowsy, inactive alert, active } \\
\text { awake, crying, indeterminate } \\
\text { sleep. }\end{array}$ & $\begin{array}{l}\text { Maternal psychopathology } \\
\text { measurement: SCID diagnosis of } \\
\text { depression, and self-report } \\
\text { measures on depression, anxiety } \\
\text { and anger. } \\
\text { The infants of the depressed } \\
\text { mothers had more sleep } \\
\text { difficulties such as less time in } \\
\text { deep sleep and more time in } \\
\text { disorganised sleep. }\end{array}$ \\
\hline $\begin{array}{l}\text { Gregory et al } \\
(2005)^{46}\end{array}$ & $\begin{array}{l}\text { Cross- } \\
\text { sectional }\end{array}$ & 6612 & $\begin{array}{l}\text { Range=3-4 } \\
\text { years } \\
\text { Age grouping: } \\
\text { childhood. }\end{array}$ & N/A & $\begin{array}{l}\text { Parental report: hard to go to } \\
\text { sleep, frequent awakenings, } \\
\text { nightmares, and early waking. }\end{array}$ & $\begin{array}{l}\text { Family psychopathology } \\
\text { measurement: parent-report of } \\
\text { family disorganization and } \\
\text { depression. } \\
\text { Maternal depression and family } \\
\text { disorganization were associated } \\
\text { with sleep problems and anxiety } \\
\text { in twins. }\end{array}$ \\
\hline $\begin{array}{l}\text { Halal et al } \\
(2021)^{36}\end{array}$ & Longitudinal & 2222 & $\begin{array}{l}\text { Age=Newborns } \\
\text { Age grouping: } \\
\text { infancy. }\end{array}$ & $\begin{array}{l}\text { Actigraphy: sleep duration, } \\
\text { night awakenings and sleep } \\
\text { efficiency. }\end{array}$ & $\begin{array}{l}\text { Brief Infant Sleep Questionnaire: } \\
\text { sleep duration and night } \\
\text { awakenings. }\end{array}$ & $\begin{array}{l}\text { Maternal psychopathology } \\
\text { measurement: Edinburgh } \\
\text { Postnatal Depression Scale. } \\
\text { Prenatal maternal depression } \\
\text { predicted more sleep problems in } \\
\text { newborns. }\end{array}$ \\
\hline $\begin{array}{l}\text { Hiscock \& } \\
\text { Wake } \\
(2001)^{41}\end{array}$ & $\begin{array}{l}\text { Cross- } \\
\text { sectional }\end{array}$ & 738 & $\begin{array}{l}\text { Range }=6-12 \\
\text { months } \\
\text { Age grouping: } \\
\text { infancy. }\end{array}$ & N/A & $\begin{array}{l}\text { Maternal report: infant sleeping in } \\
\text { the parent's bed, being nursed to } \\
\text { sleep, time to fall asleep, night } \\
\text { awakenings, and naps duration. }\end{array}$ & $\begin{array}{l}\text { Maternal psychopathology } \\
\text { measurement: Edinburgh } \\
\text { Postnatal Depression Scale. } \\
\text { Infant sleep problems were } \\
\text { associated with maternal } \\
\text { postnatal depression scores. }\end{array}$ \\
\hline $\begin{array}{l}\text { Martin et al } \\
(2007)^{49}\end{array}$ & $\begin{array}{l}\text { Cross- } \\
\text { sectional }\end{array}$ & $\begin{array}{l}5107 \\
\text { infants } \\
4983 \\
\text { pre- } \\
\text { school }\end{array}$ & $\begin{array}{l}\text { Range }= \\
\text { Newborns and } \\
4-5 \text { years } \\
\text { Age grouping: } \\
\text { infancy and } \\
\text { children. }\end{array}$ & N/A & $\begin{array}{l}\text { Maternal report: whether their } \\
\text { child's sleep was a problem (no, } \\
\text { mild, moderate or severe } \\
\text { problem). }\end{array}$ & $\begin{array}{l}\text { Parents psychopathology } \\
\text { measurement: the Kessler- } 6 \text {. } \\
\text { Preschool sleep problems were } \\
\text { associated with poor maternal } \\
\text { general health. }\end{array}$ \\
\hline $\begin{array}{l}\text { Morales- } \\
\text { Munoz et al } \\
(2018)^{52}\end{array}$ & Longitudinal & 1221 & $\begin{array}{l}\text { Age= } \\
\text { Newborns } \\
\text { Age grouping: } \\
\text { infancy. }\end{array}$ & N/A & $\begin{array}{l}\text { The Brief Infant Sleep } \\
\text { Questionnaire: number of } \\
\text { nocturnal sleep hours; number of } \\
\text { daytime sleep hours; total number } \\
\text { of sleep hours per day; and } \\
\text { method for falling asleep. }\end{array}$ & $\begin{array}{l}\text { Maternal psychopathology } \\
\text { measurement: The Alcohol Use } \\
\text { Disorders Identification Test, The } \\
\text { Global Seasonality Score, The List } \\
\text { of Threatening Experiences, The } \\
\text { State-Trait Anxiety Inventory, The } \\
\text { Center for Epidemiological } \\
\text { Studies Depression Scale and The } \\
\text { Adult ADHD Self-Report Scale. } \\
\text { Several maternal risk factors, } \\
\text { including anxiety, depression, } \\
\text { insomnia or ADHD during } \\
\text { pregnancy were related to sleep } \\
\text { difficulties. }\end{array}$ \\
\hline
\end{tabular}

(Continued) 
Table I (Continued).

\begin{tabular}{|c|c|c|c|c|c|c|}
\hline & \multirow{2}{*}{$\begin{array}{l}\text { Study } \\
\text { Design }\end{array}$} & \multirow[t]{2}{*}{$\mathbf{N}$} & \multirow{2}{*}{$\begin{array}{l}\text { Age/Age } \\
\text { Grouping }\end{array}$} & \multicolumn{2}{|c|}{ Sleep Measure } & \multirow[t]{2}{*}{ Main Findings } \\
\hline & & & & Objective & Subjective & \\
\hline $\begin{array}{l}\text { O'Connor } \\
\text { et al }(2007)^{37}\end{array}$ & Longitudinal & 11,490 & $\begin{array}{l}\text { Age }= \\
\text { Newborns } \\
\text { Age grouping: } \\
\text { infancy. }\end{array}$ & $N / A$ & $\begin{array}{l}\text { Parental report: amount of sleep, } \\
\text { frequency of awakening, child } \\
\text { regularly refuses to go to bed, } \\
\text { wakes very early, difficulty going } \\
\text { to sleep, nightmares, get up after } \\
\text { being put to bed, woke in the } \\
\text { night, or got up after few hours } \\
\text { sleep. }\end{array}$ & $\begin{array}{l}\text { Maternal psychopathology } \\
\text { measurement: Crown-Crisp } \\
\text { experiential index and the } \\
\text { Edinburgh Postnatal Depression } \\
\text { Scale. } \\
\text { Higher levels of prenatal maternal } \\
\text { depression and anxiety predicted } \\
\text { more sleep difficulties at } 18 \text { and } \\
30 \text { months. }\end{array}$ \\
\hline $\begin{array}{l}\text { Petzoldt et al } \\
(2016)^{44}\end{array}$ & Longitudinal & 286 & $\begin{array}{l}\text { Age }= \\
\text { Newborns } \\
\text { Age grouping: } \\
\text { infancy. }\end{array}$ & $\mathrm{N} / \mathrm{A}$ & Baby-DIPS: sleeping problems. & $\begin{array}{l}\text { Maternal psychopathology } \\
\text { measurement: Composite } \\
\text { International Diagnostic Interview } \\
\text { for Women (CIDI-V) to assess } \\
\text { DSM-IV anxiety and depressive } \\
\text { disorders. } \\
\text { Infant sleeping difficulties were } \\
\text { associated with maternal } \\
\text { depressive and comorbid anxiety } \\
\text { disorders irrespective of maternal } \\
\text { parity. }\end{array}$ \\
\hline $\begin{array}{l}\text { Reid et al } \\
(2009)^{45}\end{array}$ & $\begin{array}{l}\text { Cross- } \\
\text { sectional }\end{array}$ & 8868 & $\begin{array}{l}\text { Range }=2-3 \\
\text { years } \\
\text { Age grouping: } \\
\text { toddlers. }\end{array}$ & $N / A$ & $\begin{array}{l}\text { Parental report: trouble falling } \\
\text { asleep, particular and long } \\
\text { bedtime routine, and waking up } \\
\text { several times at night. }\end{array}$ & $\begin{array}{l}\text { Maternal psychopathology } \\
\text { measurement: } 12 \text {-item short- } \\
\text { form of the Center for } \\
\text { Epidemiologic Studies - } \\
\text { depression scale. } \\
\text { Maternal symptoms of anxiety } \\
\text { and depression during the first } \\
\text { year of the child's life were both } \\
\text { associated with child nocturnal } \\
\text { awakening at } 6 \text { and } 18 \text { months. }\end{array}$ \\
\hline $\begin{array}{l}\text { Schuetze } \\
\text { et al }(2006)^{51}\end{array}$ & Longitudinal & 118 & $\begin{array}{l}\text { Age }= \\
\text { Newborns } \\
\text { Age grouping: } \\
\text { infancy. }\end{array}$ & $N / A$ & $\begin{array}{l}\text { The Maternal Cognitions About } \\
\text { Infant Sleep: five subscales on } \\
\text { Limit Setting, Anger, Doubt, } \\
\text { Feeding, and Safety. }\end{array}$ & $\begin{array}{l}\text { Maternal psychopathology } \\
\text { measurement: The Brief Symptom } \\
\text { Inventory. } \\
\text { Prenatal exposure to cocaine was } \\
\text { significantly associated with more } \\
\text { severe sleep difficulties in } \\
\text { newborns and maternal anxiety } \\
\text { mediated the association. }\end{array}$ \\
\hline $\begin{array}{l}\text { Seifer et al } \\
(1996)^{53}\end{array}$ & Longitudinal & 182 & $\begin{array}{l}\text { Age grouping: } \\
\text { toddlers. }\end{array}$ & $\mathrm{N} / \mathrm{A}$ & $\begin{array}{l}\text { The Sleep Habits Questionnaire: } \\
\text { total sleep time, bedtime } \\
\text { struggles, sleep behavior, night } \\
\text { waking, morning waking, and } \\
\text { daytime sleepiness. }\end{array}$ & $\begin{array}{l}\text { Maternal psychopathology } \\
\text { measurement: maternal diagnostic } \\
\text { classification. } \\
\text { Poorly functioning families had } \\
\text { children whose sleep habits were } \\
\text { less optimal. }\end{array}$ \\
\hline $\begin{array}{l}\text { Shang et al } \\
(2006)^{47}\end{array}$ & $\begin{array}{l}\text { Cross- } \\
\text { sectional }\end{array}$ & 1391 & $\begin{array}{l}\text { Range=4-9 } \\
\text { years } \\
\text { Age grouping: } \\
\text { childhood. }\end{array}$ & $N / A$ & $\begin{array}{l}\text { The Sleep Habit Questionnaire: } \\
\text { early insomnia, late sleep, night } \\
\text { wakening, sleep talking, } \\
\text { sleepwalking, nightmare, enuresis, } \\
\text { bruxism and snoring. }\end{array}$ & $\begin{array}{l}\text { Maternal psychopathology } \\
\text { measurement: The Chinese } \\
\text { Health Questionnaire. } \\
\text { Parental distress, including } \\
\text { maternal depression, was } \\
\text { significantly associated with } \\
\text { children's sleep problems. }\end{array}$ \\
\hline
\end{tabular}

(Continued) 
Table I (Continued).

\begin{tabular}{|c|c|c|c|c|c|c|}
\hline & \multirow{2}{*}{$\begin{array}{l}\text { Study } \\
\text { Design }\end{array}$} & \multirow[t]{2}{*}{$\mathbf{N}$} & \multirow{2}{*}{$\begin{array}{l}\text { Age/Age } \\
\text { Grouping }\end{array}$} & \multicolumn{2}{|c|}{ Sleep Measure } & \multirow[t]{2}{*}{ Main Findings } \\
\hline & & & & Objective & Subjective & \\
\hline $\begin{array}{l}\text { Stoléru et al } \\
(1997)^{42}\end{array}$ & Longitudinal & 85 & $\begin{array}{l}\text { Range=I-12 } \\
\text { years } \\
\text { Age grouping: } \\
\text { infancy, } \\
\text { toddlers, } \\
\text { childhood, early } \\
\text { adolescence. }\end{array}$ & N/A & $\begin{array}{l}\text { The Child Behavior Checklist: } \\
\text { sleep problems. }\end{array}$ & $\begin{array}{l}\text { Maternal psychopathology } \\
\text { measurement: diagnosis of } \\
\text { unipolar and bipolar affective } \\
\text { illness. } \\
\text { Sleep problems were more } \\
\text { frequent and severe in children of } \\
\text { affectively ill mothers. }\end{array}$ \\
\hline $\begin{array}{l}\text { Warren et al } \\
(2003)^{50}\end{array}$ & $\begin{array}{l}\text { Cross- } \\
\text { sectional }\end{array}$ & 94 & $\begin{array}{l}\text { Age= } \\
\text { Newborns } \\
\text { Age grouping: } \\
\text { infancy. }\end{array}$ & Videotaping & $\begin{array}{l}\text { The Sleep Habits Questionnaire, } \\
\text { Sleep logs: early insomnia, late } \\
\text { sleep, night wakening, sleep } \\
\text { duration. }\end{array}$ & $\begin{array}{l}\text { Maternal psychopathology } \\
\text { measurement: diagnosis of panic } \\
\text { disorder. } \\
\text { Infants from the 4-month cohort } \\
\text { with panic disorder mothers had } \\
\text { more awakenings and greater } \\
\text { time awake during the night at } 8 \\
\text { months. }\end{array}$ \\
\hline $\begin{array}{l}\text { Ystrom et al } \\
(2017)^{43}\end{array}$ & Longitudinal & 14,926 & $\begin{array}{l}\text { Age= } \\
\text { Newborns } \\
\text { Age grouping: } \\
\text { infancy. }\end{array}$ & N/A & $\begin{array}{l}\text { Parental report: nocturnal } \\
\text { awakenings. }\end{array}$ & $\begin{array}{l}\text { Maternal psychopathology } \\
\text { measurement: Hopkins Symptom } \\
\text { Checklist (SCL-8). } \\
\text { Maternal symptoms of anxiety } \\
\text { and depression in infants were } \\
\text { both associated with child } \\
\text { nocturnal awakening at } 6 \text { and } 18 \\
\text { months. }\end{array}$ \\
\hline \multicolumn{7}{|c|}{ Sleep and Disrupted Attachment } \\
\hline $\begin{array}{l}\text { Belanger et al } \\
(2018)^{57}\end{array}$ & Longitudinal & 64 & $\begin{array}{l}\text { Mean }=25.35 \\
\text { months } \\
\text { Age grouping: } \\
\text { toddlers. }\end{array}$ & $\begin{array}{l}\text { Actigraphy: sleep duration, } \\
\text { sleep efficiency. }\end{array}$ & $\begin{array}{l}\text { Sleep diaries, Child Behavior } \\
\text { Checklist: sleep duration, sleep } \\
\text { efficiency, sleep difficulties. }\end{array}$ & $\begin{array}{l}\text { Securely attached children } \\
\text { subsequently slept more at night } \\
\text { and had higher sleep efficiency. }\end{array}$ \\
\hline $\begin{array}{l}\text { Beijers et al } \\
(2011)^{60}\end{array}$ & Longitudinal & 193 & $\begin{array}{l}\text { Age= } \\
\text { Newborns } \\
\text { Age grouping: } \\
\text { infancy. }\end{array}$ & N/A & Sleep diaries: night awakenings. & $\begin{array}{l}\text { Infants with an insecure-resistant } \\
\text { attachment style at } 12 \text { months of } \\
\text { age woke up more during the } \\
\text { night in their first } 6 \text { months of life } \\
\text { than the other infants. }\end{array}$ \\
\hline $\begin{array}{l}\text { Bilgin \& } \\
\text { Wolke } \\
(2020)^{63}\end{array}$ & Longitudinal & 105 & $\begin{array}{l}\text { Age= } \\
\text { Newborns } \\
\text { Age grouping: } \\
\text { infancy. }\end{array}$ & N/A & $\begin{array}{l}\text { Maternal report: symptoms of } \\
\text { sleeping problems. }\end{array}$ & $\begin{array}{l}\text { Sleep problems in infants at } 3 \\
\text { months were associated with } \\
\text { disorganized attachment with the } \\
\text { mother at } 18 \text { months. }\end{array}$ \\
\hline $\begin{array}{l}\text { McNamara } \\
\text { et al }(2003)^{62}\end{array}$ & Longitudinal & 342 & $\begin{array}{l}\text { Age= } \\
\text { Newborns } \\
\text { Age grouping: } \\
\text { infancy. }\end{array}$ & N/A & Maternal report: sleep problems. & $\begin{array}{l}\text { Infants with insecure-resistant } \\
\text { attachments had greater numbers } \\
\text { of night wakings and longer mean } \\
\text { durations of night waking } \\
\text { episodes than infants with } \\
\text { insecure-avoidant attachment } \\
\text { style. }\end{array}$ \\
\hline $\begin{array}{l}\text { Pennestri } \\
\text { et al }(2015)^{58}\end{array}$ & Longitudinal & 134 & $\begin{array}{l}\text { Age= } \\
\text { Newborns } \\
\text { Age grouping: } \\
\text { infancy. }\end{array}$ & N/A & $\begin{array}{l}\text { Maternal report: duration of } \\
\text { sleep, bedtime, awakenings, and } \\
\text { periods of time in bed. }\end{array}$ & $\begin{array}{l}\text { Infants with disorganised } \\
\text { attachment had more sleep } \\
\text { difficulties than infants with } \\
\text { secure or ambivalent attachment } \\
\text { style. }\end{array}$ \\
\hline
\end{tabular}

(Continued) 
Table I (Continued).

\begin{tabular}{|c|c|c|c|c|c|c|}
\hline & \multirow{2}{*}{$\begin{array}{l}\text { Study } \\
\text { Design }\end{array}$} & \multirow[t]{2}{*}{$\mathbf{N}$} & \multirow{2}{*}{$\begin{array}{l}\text { Age/Age } \\
\text { Grouping }\end{array}$} & \multicolumn{2}{|c|}{ Sleep Measure } & \multirow[t]{2}{*}{ Main Findings } \\
\hline & & & & Objective & Subjective & \\
\hline $\begin{array}{l}\text { Simard et al } \\
(2013)^{59}\end{array}$ & Longitudinal & 55 & $\begin{array}{l}\text { Age }=18 \text { months } \\
\text { Age grouping: } \\
\text { toddlers. }\end{array}$ & Actigraphy & $\begin{array}{l}\text { Sleep diaries: sleep efficiency, } \\
\text { wake duration at night, sleep } \\
\text { duration. }\end{array}$ & $\begin{array}{l}\text { Higher resistance attachment } \\
\text { behavior predicted longer wake } \\
\text { duration at night in children. }\end{array}$ \\
\hline $\begin{array}{l}\text { Zentall et al } \\
(2012)^{61}\end{array}$ & Longitudinal & 46 & $\begin{array}{l}\text { Age= } \\
\text { Newborns } \\
\text { Age grouping: } \\
\text { infancy. }\end{array}$ & N/A & Parent reported night waking. & $\begin{array}{l}\text { Infants with a secure pattern of } \\
\text { attachment with mothers had } \\
\text { lower number of night wakings } \\
\text { over time. }\end{array}$ \\
\hline \multicolumn{7}{|c|}{ Sleep and Childhood Maltreatment } \\
\hline $\begin{array}{l}\text { April- } \\
\text { Sanders et al } \\
(202 I)^{74}\end{array}$ & Longitudinal & 2491 & $\begin{array}{l}\text { Range }=5-9 \text { and } \\
10-16 \text { years } \\
\text { Age grouping: } \\
\text { childhood and } \\
\text { adolescence. }\end{array}$ & $N / A$ & $\begin{array}{l}\text { Parent and youth report; } \\
\text { prevalence of sleep disturbances. }\end{array}$ & $\begin{array}{l}\text { Childhood adversity was } \\
\text { associated with sleep disturbances } \\
\text { in youth of } 10-16 \text { years of age, } \\
\text { but not in 5-9 years of olds. }\end{array}$ \\
\hline $\begin{array}{l}\text { Glod et al } \\
(1997)^{71}\end{array}$ & $\begin{array}{l}\text { Cross- } \\
\text { sectional }\end{array}$ & 44 & $\begin{array}{l}\text { Range }=6-12 \\
\text { years } \\
\text { Age grouping: } \\
\text { childhood and } \\
\text { early } \\
\text { adolescence. }\end{array}$ & $\begin{array}{l}\text { Actigraphy: nocturnal } \\
\text { activity and algorithmic } \\
\text { estimation of sleep } \\
\text { initiation and continuity. }\end{array}$ & N/A & $\begin{array}{l}\text { Abused children were twice as } \\
\text { active at night as normal and } \\
\text { depressed children. }\end{array}$ \\
\hline $\begin{array}{l}\text { Hamilton } \\
\text { et al }(2018)^{66}\end{array}$ & $\begin{array}{l}\text { Cross- } \\
\text { sectional }\end{array}$ & 102 & $\begin{array}{l}\text { Range=18-22 } \\
\text { years } \\
\text { Age grouping: } \\
\text { young } \\
\text { adulthood. }\end{array}$ & N/A & $\begin{array}{l}\text { Sleep diary: sleep duration and } \\
\text { insomnia symptoms. }\end{array}$ & $\begin{array}{l}\text { Only childhood emotional neglect } \\
\text { significantly predicted higher } \\
\text { levels of insomnia symptoms. }\end{array}$ \\
\hline $\begin{array}{l}\text { Kaubrys et al } \\
(2021)^{67}\end{array}$ & $\begin{array}{l}\text { Cross- } \\
\text { sectional }\end{array}$ & 181 & $\begin{array}{l}\text { Age grouping: } \\
\text { college } \\
\text { students. }\end{array}$ & N/A & $\begin{array}{l}\text { Self-reports on sleep: sleep } \\
\text { efficiency, sleep duration, sleep } \\
\text { latency, sleep quality, and restful } \\
\text { sleep. }\end{array}$ & $\begin{array}{l}\text { Experiencing more daily stressors } \\
\text { than usual was significantly } \\
\text { associated with delayed sleep } \\
\text { latency and lower sleep efficiency. } \\
\text { Students who reported more } \\
\text { childhood maltreatment also } \\
\text { reported significantly lower } \\
\text { quality of sleep and feeling less } \\
\text { rested upon awakening. }\end{array}$ \\
\hline $\begin{array}{l}\text { McPhie et al } \\
(2014)^{68}\end{array}$ & Longitudinal & 73 & $\begin{array}{l}\text { Mean }=15.8 \\
\text { Age grouping: } \\
\text { adolescence. }\end{array}$ & N/A & $\begin{array}{l}\text { Self-reports on current sleep } \\
\text { disturbances. }\end{array}$ & $\begin{array}{l}\text { More severe childhood } \\
\text { maltreatment was related to } \\
\text { increased sleep problems during } \\
\text { adolescence. } \\
\text { Psychological distress was a } \\
\text { significant mediator of the } \\
\text { childhood maltreatment- } \\
\text { adolescent sleep disturbance } \\
\text { association. }\end{array}$ \\
\hline $\begin{array}{l}\text { Noll et al } \\
(2006)^{73}\end{array}$ & Longitudinal & 147 & $\begin{array}{l}\text { Range=6-16 } \\
\text { years } \\
\text { Age grouping: } \\
\text { childhood and } \\
\text { adolescence. }\end{array}$ & N/A & $\begin{array}{l}\text { Subjective reports of sleep: typical } \\
\text { sleeping patterns and sleep } \\
\text { disturbances. }\end{array}$ & $\begin{array}{l}\text { Sexually abused female } \\
\text { adolescents reported significantly } \\
\text { greater rates of sleep } \\
\text { disturbances than controls. }\end{array}$ \\
\hline
\end{tabular}

(Continued) 
Table I (Continued).

\begin{tabular}{|c|c|c|c|c|c|c|}
\hline & \multirow{2}{*}{$\begin{array}{l}\text { Study } \\
\text { Design }\end{array}$} & \multirow[t]{2}{*}{$\mathbf{N}$} & \multirow{2}{*}{$\begin{array}{l}\text { Age/Age } \\
\text { Grouping }\end{array}$} & \multicolumn{2}{|c|}{ Sleep Measure } & \multirow[t]{2}{*}{ Main Findings } \\
\hline & & & & Objective & Subjective & \\
\hline $\begin{array}{l}\text { Turner et al } \\
(2020)^{69}\end{array}$ & $\begin{array}{l}\text { Cross- } \\
\text { sectional }\end{array}$ & 2910 & $\begin{array}{l}\text { Range=14-17 } \\
\text { years } \\
\text { Age grouping: } \\
\text { adolescence. }\end{array}$ & $\mathrm{N} / \mathrm{A}$ & $\begin{array}{l}\text { Subjective Reports of sleep } \\
\text { experiences: time to fall asleep, } \\
\text { waking during the night, and hours } \\
\text { of sleep. }\end{array}$ & $\begin{array}{l}\text { All types of childhood } \\
\text { maltreatment were significantly } \\
\text { related to increased odds of } \\
\text { taking more than } 10 \text { minutes to } \\
\text { fall asleep, fewer hours slept on } \\
\text { weekdays and waking more often } \\
\text { during the night. }\end{array}$ \\
\hline $\begin{array}{l}\text { Wang et al } \\
(2016)^{72}\end{array}$ & $\begin{array}{l}\text { Cross- } \\
\text { sectional }\end{array}$ & 9582 & $\begin{array}{l}\text { Range=13-18 } \\
\text { years } \\
\text { Age grouping: } \\
\text { adolescence } \\
\text { and young } \\
\text { adulthood. }\end{array}$ & $\mathrm{N} / \mathrm{A}$ & $\begin{array}{l}\text { The International Classification of } \\
\text { Sleep Disorders II: risk of } \\
\text { insomnia. }\end{array}$ & $\begin{array}{l}\text { Adolescents exposed to at least } \\
\text { one childhood adversity of any } \\
\text { type were more likely to } \\
\text { experience insomnia than } \\
\text { nonexposed children. }\end{array}$ \\
\hline $\begin{array}{l}\text { Xiao et al } \\
(2019)^{70}\end{array}$ & $\begin{array}{l}\text { Cross- } \\
\text { sectional }\end{array}$ & 153,547 & $\begin{array}{l}\text { Mean=I5.0 } \\
\text { years } \\
\text { Age grouping: } \\
\text { adolescence. }\end{array}$ & $\mathrm{N} / \mathrm{A}$ & $\begin{array}{l}\text { The Chinese Version of the } \\
\text { Pittsburgh Sleep Quality Index: } \\
\text { sleep disturbance. }\end{array}$ & $\begin{array}{l}\text { Sleep disturbance was significantly } \\
\text { associated with physical abuse, } \\
\text { emotional abuse, sexual abuse, } \\
\text { physical neglect, and emotional } \\
\text { neglect in adolescents. }\end{array}$ \\
\hline \multicolumn{7}{|c|}{ Sleep and Impulsivity } \\
\hline $\begin{array}{l}\text { Fallone et al } \\
(2001)^{79}\end{array}$ & $\begin{array}{l}\text { Cross- } \\
\text { sectional }\end{array}$ & 82 & $\begin{array}{l}\text { Mean=11.9 } \\
\text { years } \\
\text { Age grouping: } \\
\text { early } \\
\text { adolescence. }\end{array}$ & $\begin{array}{l}\text { Actigraphy, } \\
\text { Polysomnography: daytime } \\
\text { sleep latency. }\end{array}$ & $\begin{array}{l}\text { Multiple sleep latency test, } \\
\text { Subjective sleepiness ratings: sleep } \\
\text { latency and subjective sleepiness. }\end{array}$ & $\begin{array}{l}\text { Sleepiness following acute sleep } \\
\text { restriction was not sufficient to } \\
\text { produce deficits on impulsivity } \\
\text { and sustained attention. }\end{array}$ \\
\hline $\begin{array}{l}\text { Gershon } \\
\text { et al }(2019)^{77}\end{array}$ & $\begin{array}{l}\text { Cross- } \\
\text { sectional }\end{array}$ & 59 & $\begin{array}{l}\text { Range=13-19 } \\
\text { years } \\
\text { Age grouping: } \\
\text { adolescence } \\
\text { and young } \\
\text { adulthood. }\end{array}$ & $\mathrm{N} / \mathrm{A}$ & $\begin{array}{l}\text { Self-report questionnaire: } \\
\text { bedtime, rise time, and sleep } \\
\text { duration. }\end{array}$ & $\begin{array}{l}\text { Greater change in sleep duration } \\
\text { between school days and } \\
\text { weekends was related to higher } \\
\text { levels of impulsivity among } \\
\text { adolescents with bipolar disorder } \\
\text { compared to controls. }\end{array}$ \\
\hline $\begin{array}{l}\text { Grant \& } \\
\text { Chamberlain } \\
(2018)^{76}\end{array}$ & $\begin{array}{l}\text { Cross- } \\
\text { sectional }\end{array}$ & 373 & $\begin{array}{l}\text { Range=18-29 } \\
\text { years } \\
\text { Age grouping: } \\
\text { young } \\
\text { adulthood. }\end{array}$ & $\mathrm{N} / \mathrm{A}$ & $\begin{array}{l}\text { The Epworth Sleepiness Scale: } \\
\text { sleepiness. }\end{array}$ & $\begin{array}{l}\text { Higher levels of sleepiness were } \\
\text { significantly associated with a } \\
\text { range of impulsive measures. }\end{array}$ \\
\hline $\begin{array}{l}\text { Gruber et al } \\
(2012)^{81}\end{array}$ & $\begin{array}{l}\text { Cross- } \\
\text { sectional }\end{array}$ & 34 & $\begin{array}{l}\text { Range:7-II } \\
\text { Age grouping: } \\
\text { Childhood }\end{array}$ & $\begin{array}{l}\text { Actigraphy: sleep duration, } \\
\text { sleep quality }\end{array}$ & $\begin{array}{l}\text { The Modified Epworth Sleepiness } \\
\text { Scale }\end{array}$ & $\begin{array}{l}\text { A cumulative extension of sleep } \\
\text { duration of } 27.36 \text { minutes was } \\
\text { associated with improvement in } \\
\text { emotional lability and restless- } \\
\text { impulsive behaviour and a } \\
\text { significant reduction in reported } \\
\text { daytime sleepiness. } \\
\text { A cumulative restriction of sleep } \\
\text { of } 54.04 \text { minutes was associated } \\
\text { with detectable deterioration on } \\
\text { emotion regulation and } \\
\text { impulsivity. }\end{array}$ \\
\hline $\begin{array}{l}\text { Medeiros } \\
\text { et al }(2005)^{80}\end{array}$ & $\begin{array}{l}\text { Cross- } \\
\text { sectional }\end{array}$ & 1180 & $\begin{array}{l}\text { Range=7-10 } \\
\text { years } \\
\text { Age grouping: } \\
\text { childhood. }\end{array}$ & $\mathrm{N} / \mathrm{A}$ & $\begin{array}{l}\text { Parental report: sleep disorders } \\
\text { and sleep-related respiratory } \\
\text { disorders. }\end{array}$ & $\begin{array}{l}\text { Children with non-respiratory } \\
\text { sleep disorders had greater } \\
\text { predisposition to impulsivity than } \\
\text { children without sleep disorders. }\end{array}$ \\
\hline
\end{tabular}

(Continued) 
Table I (Continued).

\begin{tabular}{|c|c|c|c|c|c|c|}
\hline & \multirow{2}{*}{$\begin{array}{l}\text { Study } \\
\text { Design }\end{array}$} & \multirow[t]{2}{*}{$\mathbf{N}$} & \multirow{2}{*}{$\begin{array}{l}\text { Age/Age } \\
\text { Grouping }\end{array}$} & \multicolumn{2}{|c|}{ Sleep Measure } & \multirow[t]{2}{*}{ Main Findings } \\
\hline & & & & Objective & Subjective & \\
\hline $\begin{array}{l}\text { Rossa et al } \\
(2014)^{78}\end{array}$ & $\begin{array}{l}\text { Cross- } \\
\text { sectional }\end{array}$ & 19 & $\begin{array}{l}\text { Mean=20.16 } \\
\text { years } \\
\text { Age grouping: } \\
\text { young } \\
\text { adulthood. }\end{array}$ & N/A & $\begin{array}{l}\text { Karolinska Sleepiness Scale: } \\
\text { sleepiness. }\end{array}$ & $\begin{array}{l}\text { An acute sleep restriction } \\
\text { paradigm significantly impacted on } \\
\text { affective experiences and } \\
\text { increased impulsive and high-risk } \\
\text { behaviour in young adults. }\end{array}$ \\
\hline \multicolumn{6}{|c|}{ Sleep and Emotion dysregulation } & \\
\hline $\begin{array}{l}\text { Alfano et al } \\
(2020)^{86}\end{array}$ & $\begin{array}{l}\text { Cross- } \\
\text { sectional }\end{array}$ & 53 & $\begin{array}{l}\text { Mean=9.0 } \\
\text { Age grouping: } \\
\text { Childhood }\end{array}$ & $\begin{array}{l}\text { Polysomnography and } \\
\text { actigraphy: sleep duration } \\
\text { and sleep quality. }\end{array}$ & $\mathrm{N} / \mathrm{A}$ & $\begin{array}{l}\text { Deleterious alterations were } \\
\text { observed in children's affect, } \\
\text { emotional arousal, facial } \\
\text { expressions, and emotion } \\
\text { regulation after sleep restriction. }\end{array}$ \\
\hline $\begin{array}{l}\text { Baum et al } \\
(2014)^{85}\end{array}$ & $\begin{array}{l}\text { Cross- } \\
\text { sectional }\end{array}$ & 50 & $\begin{array}{l}\text { Range }=14-17 \\
\text { years } \\
\text { Age grouping: } \\
\text { adolescence. }\end{array}$ & Actigraphy: sleep duration. & Sleep diary: sleep duration. & $\begin{array}{l}\text { Several nights of sleep restriction } \\
\text { adversely affected adolescents' } \\
\text { mood and ability to regulate their } \\
\text { emotions. }\end{array}$ \\
\hline $\begin{array}{l}\text { Berger et al } \\
(2012)^{87}\end{array}$ & $\begin{array}{l}\text { Cross- } \\
\text { sectional }\end{array}$ & 10 & $\begin{array}{l}\text { Range }=30-36 \\
\text { months } \\
\text { Age grouping: } \\
\text { toddlers. }\end{array}$ & Actigraphy: sleep duration. & $\begin{array}{l}\text { Children's Sleep Habits } \\
\text { Questionnaire, } \\
\text { Sleep diary: sleep duration. }\end{array}$ & $\begin{array}{l}\text { Sleep restriction resulted in a } \\
\text { reduction in positive responses, } \\
\text { and an increase in negative } \\
\text { emotion responses. }\end{array}$ \\
\hline $\begin{array}{l}\text { Grove et al } \\
(2017)^{89}\end{array}$ & $\begin{array}{l}\text { Cross- } \\
\text { sectional }\end{array}$ & 481 & $\begin{array}{l}\text { Mean=23 years } \\
\text { Age grouping: } \\
\text { young } \\
\text { adulthood. }\end{array}$ & N/A & $\begin{array}{l}\text { The Pittsburgh Sleep Quality } \\
\text { Index: sleep quality. }\end{array}$ & $\begin{array}{l}\text { BPD features related to emotion } \\
\text { dysregulation were most strongly } \\
\text { associated with poor sleep quality. }\end{array}$ \\
\hline $\begin{array}{l}\text { Palmer et al } \\
(2018)^{88}\end{array}$ & $\begin{array}{l}\text { Cross- } \\
\text { sectional }\end{array}$ & 10,148 & $\begin{array}{l}\text { Range=13-18 } \\
\text { years } \\
\text { Age grouping: } \\
\text { adolescence } \\
\text { and young } \\
\text { adulthood. }\end{array}$ & N/A & Self-report: sleep problems. & $\begin{array}{l}\text { Adolescents with greater sleep } \\
\text { difficulties reported poorer } \\
\text { emotion regulation. }\end{array}$ \\
\hline $\begin{array}{l}\text { Simor et al } \\
(2010)^{91}\end{array}$ & $\begin{array}{l}\text { Cross- } \\
\text { sectional }\end{array}$ & 46 & $\mathrm{~N} / \mathrm{A}$ & N/A & $\begin{array}{l}\text { The Dream Quality } \\
\text { Questionnaire: dream } \\
\text { disturbances. }\end{array}$ & $\begin{array}{l}\text { Dream disturbances were more } \\
\text { frequent in patients with BPD } \\
\text { than in controls. }\end{array}$ \\
\hline $\begin{array}{l}\text { Wall et al } \\
(2020)^{90}\end{array}$ & Longitudinal & 217 & $\begin{array}{l}\text { Range }=12-17 \\
\text { Age grouping: } \\
\text { Adolescence }\end{array}$ & $\mathrm{N} / \mathrm{A}$ & $\begin{array}{l}\text { The School Sleep Habits Survey: } \\
\text { sleep disturbance. }\end{array}$ & $\begin{array}{l}\text { Borderline personality features } \\
\text { and emotion dysregulation were } \\
\text { significantly related to sleep } \\
\text { disturbances. }\end{array}$ \\
\hline $\begin{array}{l}\text { Zhang et al } \\
(2019)^{84}\end{array}$ & $\begin{array}{l}\text { Cross- } \\
\text { sectional }\end{array}$ & 51 & $\begin{array}{l}\text { Range }=18 \\
\text { months- } 3 \text { years } \\
\text { Age grouping: } \\
\text { toddlers. }\end{array}$ & $\mathrm{N} / \mathrm{A}$ & $\begin{array}{l}\text { The Chinese Version of the } \\
\text { Pittsburgh Sleep Quality Index: } \\
\text { sleep quality. }\end{array}$ & $\begin{array}{l}\text { Emotion regulation strategies (ie, } \\
\text { distraction and reappraisal) were } \\
\text { impaired by sleep deprivation. }\end{array}$ \\
\hline \multicolumn{7}{|c|}{ Sleep and Internalising/Externalising disorders } \\
\hline $\begin{array}{l}\text { Alfano et al } \\
(2009)^{117}\end{array}$ & $\begin{array}{l}\text { Cross- } \\
\text { sectional }\end{array}$ & 175 & $\begin{array}{l}\text { Mean=11.4 } \\
\text { years } \\
\text { Age grouping: } \\
\text { childhood. }\end{array}$ & N/A & $\begin{array}{l}\text { A sleep scale was created from } \\
\text { sleep related items from various } \\
\text { measures: sleep problems. }\end{array}$ & $\begin{array}{l}\text { There were significant } \\
\text { associations between sleep } \\
\text { problems and both anxiety and } \\
\text { depressive symptoms. }\end{array}$ \\
\hline
\end{tabular}

(Continued) 
Table I (Continued).

\begin{tabular}{|c|c|c|c|c|c|c|}
\hline & \multirow{2}{*}{$\begin{array}{l}\text { Study } \\
\text { Design }\end{array}$} & \multirow[t]{2}{*}{$\mathbf{N}$} & \multirow{2}{*}{$\begin{array}{l}\text { Age/Age } \\
\text { Grouping }\end{array}$} & \multicolumn{2}{|c|}{ Sleep Measure } & \multirow[t]{2}{*}{ Main Findings } \\
\hline & & & & Objective & Subjective & \\
\hline $\begin{array}{l}\text { Bai et al } \\
(2020)^{95}\end{array}$ & Longitudinal & 319 & $\begin{array}{l}\text { Range=II-26 } \\
\text { years } \\
\text { Age grouping: } \\
\text { childhood, } \\
\text { adolescence } \\
\text { and young } \\
\text { adulthood. }\end{array}$ & $\mathrm{N} / \mathrm{A}$ & $\begin{array}{l}\text { The Physical Symptom Checklist: } \\
\text { dysregulated sleep. }\end{array}$ & $\begin{array}{l}\text { Dysregulated sleep was } \\
\text { bidirectionally associated with } \\
\text { clinician-rated anxiety and } \\
\text { depression symptom severity. }\end{array}$ \\
\hline $\begin{array}{l}\text { Chang et al } \\
(2018)^{97}\end{array}$ & Longitudinal & 2510 & $\begin{array}{l}\text { Range }=11-12 \\
\text { years } \\
\text { Age grouping: } \\
\text { Adolescence }\end{array}$ & $\mathrm{N} / \mathrm{A}$ & Subjective reports of sleep times. & $\begin{array}{l}\text { Significant inter-relationships for } \\
\text { sleep duration and cigarette } \\
\text { smoking trajectories were found } \\
\text { during adolescence; all atypical } \\
\text { sleep duration trajectories } \\
\text { conferred increased risks of } \\
\text { cigarette smoking. } \\
\text { The effects of sleep duration and } \\
\text { cigarette smoking on later } \\
\text { internalizing problems were found } \\
\text { to vary by sex and trajectory } \\
\text { patterns. }\end{array}$ \\
\hline $\begin{array}{l}\text { Cho et al } \\
(2017)^{114}\end{array}$ & Longitudinal & 123 & $\begin{array}{l}\text { Mean }=24.43 \\
\text { years } \\
\text { Age grouping: } \\
\text { young } \\
\text { adulthood. }\end{array}$ & $\mathrm{N} / \mathrm{A}$ & Parental report: sleep duration. & $\begin{array}{l}\text { Short sleep predicted greater } \\
\text { daytime externalizing behaviors a } \\
\text { year later. }\end{array}$ \\
\hline $\begin{array}{l}\text { Conway et al } \\
(2017)^{118}\end{array}$ & Longitudinal & 1001 & $\begin{array}{l}\text { Range=24-36 } \\
\text { months } \\
\text { Age grouping: } \\
\text { toddlers. }\end{array}$ & $N / A$ & $\begin{array}{l}\text { Parental report: trouble getting to } \\
\text { sleep, bedtime resistance, sleep } \\
\text { problems. }\end{array}$ & $\begin{array}{l}\text { There were reciprocal } \\
\text { associations between trouble } \\
\text { getting to sleep and internalizing } \\
\text { problems, and unidirectional links } \\
\text { between externalizing problems } \\
\text { and bedtime resistance. }\end{array}$ \\
\hline $\begin{array}{l}\text { Gregory et al } \\
(2006)^{93}\end{array}$ & $\begin{array}{l}\text { Cross- } \\
\text { sectional }\end{array}$ & 300 & $\begin{array}{l}\text { Mean }=8.6 \text { years } \\
\text { Age grouping: } \\
\text { childhood. }\end{array}$ & $N / A$ & $\begin{array}{l}\text { The Child Sleep Habits } \\
\text { Questionnaire: sleep problems. }\end{array}$ & $\begin{array}{l}\text { A range of sleep difficulties were } \\
\text { associated with depression in } \\
\text { children. }\end{array}$ \\
\hline $\begin{array}{l}\text { Gruber et al } \\
(2020)^{110}\end{array}$ & $\begin{array}{l}\text { Cross- } \\
\text { sectional }\end{array}$ & 122 & $\begin{array}{l}\text { Range=7-II } \\
\text { Age grouping: } \\
\text { Childhood }\end{array}$ & $\begin{array}{l}\text { Actigraphy: Night-time } \\
\text { sleep, sleep schedule, and } \\
\text { sleep efficiency }\end{array}$ & $\begin{array}{l}\text { Child Sleep Habits Questionnaire, } \\
\text { parental report on daily sleep } \\
\text { logs: sleep disturbances. }\end{array}$ & $\begin{array}{l}\text { Children who were above the } \\
\text { cutoff score of the Children Sleep } \\
\text { Habits Questionnaire were less } \\
\text { likely to obtain the recommended } \\
\text { amount of sleep for their age, had } \\
\text { higher levels of internalizing and } \\
\text { externalizing symptoms and a } \\
\text { higher prevalence of clinical levels } \\
\text { of externalizing and internalizing } \\
\text { problems, had lower grades in } \\
\text { English and French and were } \\
\text { more likely to fail these subjects. }\end{array}$ \\
\hline
\end{tabular}

(Continued) 
Table I (Continued).

\begin{tabular}{|c|c|c|c|c|c|c|}
\hline & \multirow{2}{*}{$\begin{array}{l}\text { Study } \\
\text { Design }\end{array}$} & \multirow[t]{2}{*}{$\mathbf{N}$} & \multirow{2}{*}{$\begin{array}{l}\text { Age/Age } \\
\text { Grouping }\end{array}$} & \multicolumn{2}{|c|}{ Sleep Measure } & \multirow[t]{2}{*}{ Main Findings } \\
\hline & & & & Objective & Subjective & \\
\hline $\begin{array}{l}\text { Hoyniak et al } \\
(2020)^{100}\end{array}$ & Longitudinal & 119 & $\begin{array}{l}30 \text { months of } \\
\text { age } \\
\text { Age grouping: } \\
\text { Childhood }\end{array}$ & $\begin{array}{l}\text { Actigraphy: sleep duration, } \\
\text { sleep timing, sleep } \\
\text { vulnerability, and sleep } \\
\text { activity }\end{array}$ & $\begin{array}{l}\text { Parental report on daily sleep } \\
\text { diaries }\end{array}$ & $\begin{array}{l}\text { More variable sleep at } 30 \text { months } \\
\text { had higher teacher-reported } \\
\text { internalizing problems in } \\
\text { preschool. } \\
\text { Children with later sleep timing at } \\
30 \text { months had poorer cognitive } \\
\text { and academic skills at } 54 \text { months. } \\
\text { Changes in sleep from } 30 \text { to } 54 \\
\text { months were not associated with } \\
\text { any of the domains of adjustment. }\end{array}$ \\
\hline $\begin{array}{l}\text { Lavigne et al } \\
(1999)^{103}\end{array}$ & $\begin{array}{l}\text { Cross- } \\
\text { sectional }\end{array}$ & 510 & $\begin{array}{l}\text { Range }=2-5 \\
\text { Age grouping: } \\
\text { Childhood }\end{array}$ & $N / A$ & $\begin{array}{l}\text { Parental report on the amount of } \\
\text { sleep child obtained }\end{array}$ & $\begin{array}{l}\text { The relationship between less } \\
\text { sleep at night and the presence of } \\
\text { a DSM-III-R psychiatric diagnosis } \\
\text { was significant. } \\
\text { Less night sleep and less sleep in a } \\
24 \text { hour period were associated } \\
\text { with increased total behavior } \\
\text { problems on the Child Behavior } \\
\text { Checklist and with more } \\
\text { externalizing problems. }\end{array}$ \\
\hline $\begin{array}{l}\text { Lee et al } \\
(2021)^{104}\end{array}$ & $\begin{array}{l}\text { Cross- } \\
\text { sectional }\end{array}$ & 196 & $\begin{array}{l}\text { Mean }=59.6 \\
\text { months } \\
\text { Age grouping: } \\
\text { Childhood }\end{array}$ & $N / A$ & $\begin{array}{l}\text { Children's Sleep Habits } \\
\text { Questionnaire: poor and good } \\
\text { sleepers. }\end{array}$ & $\begin{array}{l}\text { Externalising problems such as } \\
\text { aggressive behaviors and attention } \\
\text { problems, rather than cognitive } \\
\text { development, are associated with } \\
\text { sleep difficulties in preschool } \\
\text { children with developmental } \\
\text { disability. }\end{array}$ \\
\hline $\begin{array}{l}\text { Madrid- } \\
\text { Valero et al } \\
(2020)^{94}\end{array}$ & $\begin{array}{l}\text { Cross- } \\
\text { sectional }\end{array}$ & $\begin{array}{l}5111 \\
\text { twin } \\
\text { pairs }\end{array}$ & $\begin{array}{l}\text { Mean }=16.32 \\
\text { years } \\
\text { Age grouping: } \\
\text { adolescence. }\end{array}$ & $N / A$ & $\begin{array}{l}\text { The Pittsburgh Sleep Quality } \\
\text { Index, The Insomnia Severity } \\
\text { Index: sleep quality and insomnia. }\end{array}$ & $\begin{array}{l}\text { Associations between sleep and } \\
\text { internalizing problems were } \\
\text { moderate and there was a large } \\
\text { genetic overlap between these } \\
\text { problems. }\end{array}$ \\
\hline $\begin{array}{l}\text { Mindell et al } \\
(2017)^{115}\end{array}$ & Longitudinal & 117 & $\begin{array}{l}\text { Range=3-18 } \\
\text { months } \\
\text { Age grouping: } \\
\text { toddlers. }\end{array}$ & $N / A$ & $\begin{array}{l}\text { The Brief Infant Sleep } \\
\text { Questionnaire: bedtime, sleep } \\
\text { duration, sleep latency and night } \\
\text { awakenings. }\end{array}$ & $\begin{array}{l}\text { Later bedtimes and less total } \\
\text { sleep predicted higher } \\
\text { internalising problem scores. }\end{array}$ \\
\hline $\begin{array}{l}\text { Morales- } \\
\text { Muñoz et al } \\
(2020)^{113}\end{array}$ & Longitudinal & 936 & $\begin{array}{l}\text { Age= } \\
\text { Newborns } \\
\text { Age grouping: } \\
\text { infancy. }\end{array}$ & $N / A$ & $\begin{array}{l}\text { The Brief Infant Sleep } \\
\text { Questionnaire, The Infant Sleep } \\
\text { Questionnaire: sleep duration, } \\
\text { sleep latency and night } \\
\text { awakenings. }\end{array}$ & $\begin{array}{l}\text { Shorter sleep and poorer sleep } \\
\text { quality in infancy were } \\
\text { prospectively related to } \\
\text { emotional and behavioural } \\
\text { symptoms in toddlers. }\end{array}$ \\
\hline $\begin{array}{l}\text { Mulraney } \\
\text { et al } \\
(2016)^{107}\end{array}$ & Longitudinal & 270 & $\begin{array}{l}\text { Range }=5-13 \\
\text { years } \\
\text { Age grouping: } \\
\text { childhood. }\end{array}$ & $N / A$ & $\begin{array}{l}\text { Children's Sleep Habits } \\
\text { Questionnaire: sleep problems. }\end{array}$ & $\begin{array}{l}\text { There was a weak bidirectional } \\
\text { relationship between sleep } \\
\text { problems and emotional } \\
\text { problems. }\end{array}$ \\
\hline $\begin{array}{l}\text { Muratori } \\
\text { et al } \\
(2019)^{101}\end{array}$ & Longitudinal & 227 & $\begin{array}{l}\text { Range=6-10 } \\
\text { years } \\
\text { Age grouping: } \\
\text { childhood. }\end{array}$ & $N / A$ & $\begin{array}{l}\text { The Sleep Disturbance Scale for } \\
\text { Children: sleep problems. }\end{array}$ & $\begin{array}{l}\text { A significant association was } \\
\text { found between increased sleep } \\
\text { problems and worsening of } \\
\text { inattentive and hyperactive } \\
\text { behavioral problems I year later. }\end{array}$ \\
\hline
\end{tabular}

(Continued) 
Table I (Continued).

\begin{tabular}{|c|c|c|c|c|c|c|}
\hline & \multirow{2}{*}{$\begin{array}{l}\text { Study } \\
\text { Design }\end{array}$} & \multirow[t]{2}{*}{$\mathbf{N}$} & \multirow{2}{*}{$\begin{array}{l}\text { Age/Age } \\
\text { Grouping }\end{array}$} & \multicolumn{2}{|c|}{ Sleep Measure } & \multirow[t]{2}{*}{ Main Findings } \\
\hline & & & & Objective & Subjective & \\
\hline $\begin{array}{l}\text { Nunes et al } \\
(2020)^{96}\end{array}$ & Longitudinal & 1729 & $\begin{array}{l}\text { Range }=|0-| \mid \\
\text { years } \\
\text { Age grouping: } \\
\text { childhood. }\end{array}$ & N/A & $\begin{array}{l}\text { Parental and self-reports: sleep } \\
\text { duration, difficulties getting to } \\
\text { sleep and changes in difficulties } \\
\text { getting to sleep. }\end{array}$ & $\begin{array}{l}\text { Sleep duration was not } \\
\text { longitudinally associated with } \\
\text { internalizing problems, but it was } \\
\text { in the cross-sectional analyses. }\end{array}$ \\
\hline $\begin{array}{l}\text { Paavonen } \\
\text { et al } \\
(2009)^{108}\end{array}$ & $\begin{array}{l}\text { Cross- } \\
\text { sectional }\end{array}$ & 297 & $\begin{array}{l}\text { Range=5-6 } \\
\text { years } \\
\text { Age grouping: } \\
\text { childhood. }\end{array}$ & N/A & $\begin{array}{l}\text { The Sleep Disturbance Scale for } \\
\text { Children: Sleep quality and sleep } \\
\text { duration. }\end{array}$ & $\begin{array}{l}\text { Both short sleep duration and } \\
\text { sleeping difficulties were } \\
\text { significantly associated with } \\
\text { children's behavioral symptoms. }\end{array}$ \\
\hline $\begin{array}{l}\text { Pieters et al } \\
(2015)^{105}\end{array}$ & Longitudinal & 555 & $\begin{array}{l}\text { Mean=13.96 } \\
\text { years } \\
\text { Age grouping: } \\
\text { early } \\
\text { adolescence. }\end{array}$ & N/A & $\begin{array}{l}\text { The Adolescent Sleep Wake Scale, } \\
\text { The Adolescent Hygiene Sleep } \\
\text { Scale: sleep quality and sleep } \\
\text { hygiene. }\end{array}$ & $\begin{array}{l}\text { Sleep problems predicted changes } \\
\text { in substance use, internalizing and } \\
\text { externalizing problems over time, } \\
\text { but problematic behaviours did } \\
\text { not predict changes in sleep } \\
\text { problems. }\end{array}$ \\
\hline $\begin{array}{l}\text { Reynolds \& } \\
\text { Alfano } \\
(2016)^{98}\end{array}$ & Longitudinal & 1364 & $\begin{array}{l}\text { Participants } \\
\text { were assessed } \\
\text { from birth to } \\
\text { age } 15\end{array}$ & N/A & $\begin{array}{l}\text { A set of questions was derived } \\
\text { from the Children's Sleep Habits } \\
\text { Questionnaire: bedtime and } \\
\text { nighttime waking problems. }\end{array}$ & $\begin{array}{l}\text { Bedtime but not nighttime waking } \\
\text { problems significantly predicted } \\
\text { adolescent internalising problems. }\end{array}$ \\
\hline $\begin{array}{l}\text { Rubens et al } \\
(2017)^{111}\end{array}$ & $\begin{array}{l}\text { Cross- } \\
\text { sectional }\end{array}$ & 285 & $\begin{array}{l}\text { Range=8-II } \\
\text { years } \\
\text { Age grouping: } \\
\text { Childhood }\end{array}$ & N/A & $\begin{array}{l}\text { Self-reports of sleep quality and } \\
\text { time in bed. }\end{array}$ & $\begin{array}{l}\text { Sleep quality was negatively } \\
\text { associated with anxiety, } \\
\text { depressive symptoms, irritability, } \\
\text { reactive aggression, and } \\
\text { delinquency engagement. }\end{array}$ \\
\hline $\begin{array}{l}\text { Quach et al } \\
(2018)^{106}\end{array}$ & Longitudinal & 4983 & $\begin{array}{l}\text { Range=4-5 } \\
\text { years } \\
\text { Age grouping: } \\
\text { childhood. }\end{array}$ & N/A & $\begin{array}{l}\text { Parental report: difficulty getting } \\
\text { to sleep at night, not happy } \\
\text { sleeping alone, waking during } \\
\text { night, and restless sleep. }\end{array}$ & $\begin{array}{l}\text { Significant bidirectional } \\
\text { associations were found between } \\
\text { sleep and externalizing problems, } \\
\text { with greater sleep problems } \\
\text { associated with later externalizing } \\
\text { behaviours. }\end{array}$ \\
\hline $\begin{array}{l}\text { Scharf et al } \\
(2013)^{102}\end{array}$ & $\begin{array}{l}\text { Cross- } \\
\text { sectional }\end{array}$ & 8950 & $\begin{array}{l}\text { Age= } 4 \text { years } \\
\text { Age grouping: } \\
\text { childhood. }\end{array}$ & N/A & $\begin{array}{l}\text { Parental report: night-time sleep } \\
\text { duration. }\end{array}$ & $\begin{array}{l}\text { Shorter nighttime sleep duration } \\
\text { was associated with higher } \\
\text { likelihood of parent-reported } \\
\text { externalizing behavioral } \\
\text { symptoms. }\end{array}$ \\
\hline $\begin{array}{l}\text { Sivertsen } \\
\text { et al } \\
(2015)^{116}\end{array}$ & Longitudinal & 32,662 & $\begin{array}{l}\text { The data were } \\
\text { collected at } \\
\text { gestational } \\
\text { week } 17, \text { I8 } \\
\text { months and } 5 \\
\text { years after } \\
\text { birth. } \\
\text { Age grouping: } \\
\text { Childhood }\end{array}$ & N/A & $\begin{array}{l}\text { Mother reported child sleep } \\
\text { duration and nocturnal } \\
\text { awakenings. }\end{array}$ & $\begin{array}{l}\text { Short sleep duration and frequent } \\
\text { nocturnal awakenings at } 18 \\
\text { months significantly predicted } \\
\text { both concurrent and later } \\
\text { incidence of emotional and } \\
\text { behavioural problems at } 5 \text { years. }\end{array}$ \\
\hline $\begin{array}{l}\text { Sivertsen } \\
\text { et al }(2021)^{99}\end{array}$ & Longitudinal & 35,075 & $\begin{array}{l}\text { Range=1.5-8 } \\
\text { years } \\
\text { Age grouping: } \\
\text { Childhood }\end{array}$ & $\mathrm{N} / \mathrm{A}$ & $\begin{array}{l}\text { Child Behavior Checklist: sleep } \\
\text { duration and nocturnal } \\
\text { awakenings. }\end{array}$ & $\begin{array}{l}\text { Short sleep duration and frequent } \\
\text { nightly awakenings at } 1.5 \text { years } \\
\text { predicted the development of } \\
\text { depressive symptoms at } 8 \text { years of } \\
\text { age. } \\
\text { Internalising problems at } 1.5 \text { years } \\
\text { predicted onset of later short } \\
\text { sleep duration. }\end{array}$ \\
\hline
\end{tabular}

(Continued) 
Table I (Continued).

\begin{tabular}{|c|c|c|c|c|c|c|}
\hline & \multirow{2}{*}{$\begin{array}{l}\text { Study } \\
\text { Design }\end{array}$} & \multirow[t]{2}{*}{$\mathbf{N}$} & \multirow{2}{*}{$\begin{array}{l}\text { Age/Age } \\
\text { Grouping }\end{array}$} & \multicolumn{2}{|c|}{ Sleep Measure } & \multirow[t]{2}{*}{ Main Findings } \\
\hline & & & & Objective & Subjective & \\
\hline $\begin{array}{l}\text { Williamson } \\
\text { et al } \\
(2020)^{1 / 2}\end{array}$ & Longitudinal & 4517 & $\begin{array}{l}\text { Range=10-11 } \\
\text { years } \\
\text { Age grouping: } \\
\text { childhood. }\end{array}$ & N/A & Parental report: sleep problems. & $\begin{array}{l}\text { Children with increased sleep } \\
\text { problems experienced greater } \\
\text { internalizing and externalizing } \\
\text { symptoms. }\end{array}$ \\
\hline $\begin{array}{l}\text { Wong et al } \\
(2009)^{109}\end{array}$ & Longitudinal & 386 & $\begin{array}{l}\text { Range=3-II } \\
\text { Age grouping: } \\
\text { Childhood }\end{array}$ & N/A & $\begin{array}{l}\text { Maternal reports on Child } \\
\text { Behavior Checklist: sleep } \\
\text { problems. }\end{array}$ & $\begin{array}{l}\text { Sleep problems at ages } 3-8 \\
\text { predicted onset of alcohol, } \\
\text { cigarette, and marijuana use } \\
\text { among boys and onset of alcohol } \\
\text { use among girls. } \\
\text { Childhood sleep problems were } \\
\text { related to maternal ratings of } \\
\text { internalising and externalising } \\
\text { problems during adolescence for } \\
\text { both boys and girls. }\end{array}$ \\
\hline
\end{tabular}

Abbreviations: ADHD, attention deficit hyperactivity disorder; fMRI, functional magnetic resonance imaging; BPD, borderline personality disorder.

Further research should specifically investigate sleep in childhood and subsequent BPD symptoms in combination with some of the relevant features described in this review. Future research should also examine whether this pathway and potential factors described here are specific to BPD or whether this could also apply to other mental health problems, such as psychosis or depression. One hypothesis could be that under the combination of specific core features of BPD, such as the ones described in this model, impairment of sleep at specific stages of the development could lead to the development of subsequent BPD symptoms, instead of other mental health problems. However, further research is still required. This will help us to better understand how early sleep associates with BPD symptoms. This would lead to a better characterization of the potential underlying mechanisms of BPD symptoms and to a better understanding of how sleep disruption in early stages might lead to the development of subsequent BPD symptoms. In addition, further studies should focus on investigating whether sleep in early childhood might play a causal role in the development of BPD symptoms. Investigation of new developmental and early intervention approaches to understand how sleep in early childhood associates with subsequent BPD symptoms could have significant clinical impact on these patients and would aid to design better targeted therapeutic interventions.

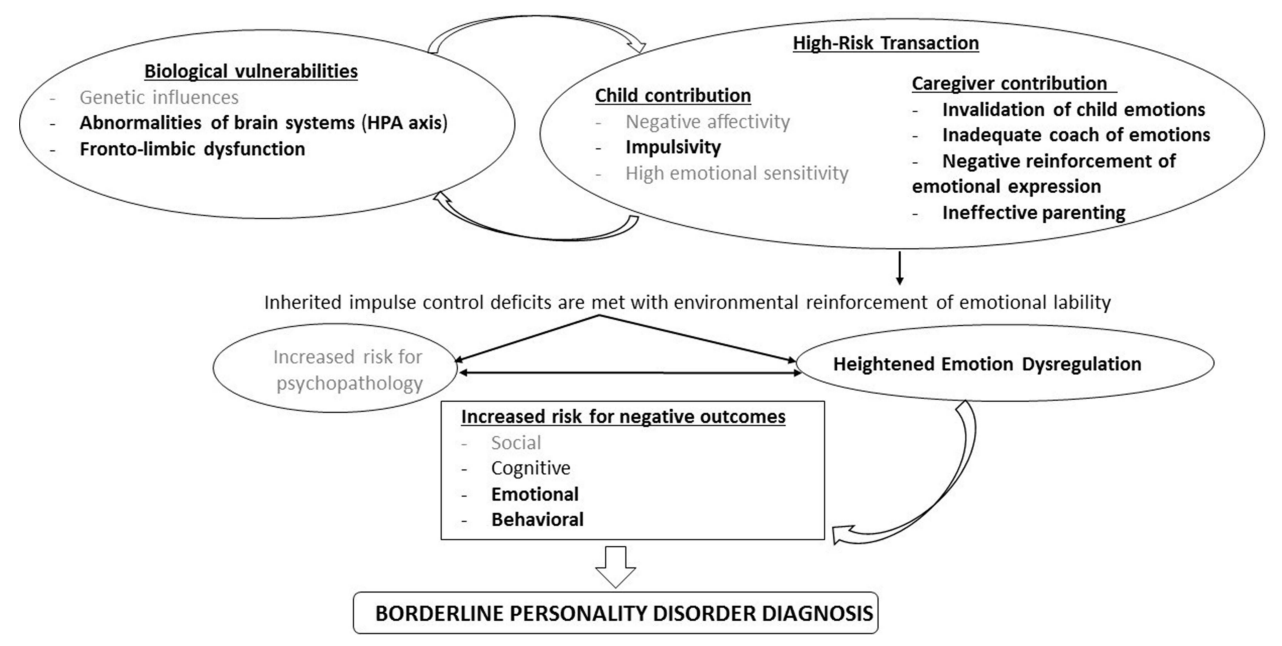

Figure 2 Adaptation of the biosocial developmental model of BPD. In this figure we present the pathways that could explain why sleep problems and subsequent BPD symptoms associate, using the biosocial developmental model by Crowell et al. In bold we have highlighted the processes that could have potential interaction with sleep problems and thus could explain the potential associations between sleep and BPD. These are HPA, prefrontal cortex, impulsivity, family psychopathology, disrupted attachment, childhood maltreatment, emotional dysregulation and internalizing/externalizing symptoms. 


\section{Disclosure}

The authors report no conflicts of interest in this work.

\section{References}

1. Carpenter RW, Trull TJ. Components of emotion dysregulation in borderline personality disorder: a review. Curr Psychiatry Rep. 2013;15(1):335. doi:10.1007/s11920-012-0335-2

2. Winsper C, Tang NKY, Marwaha S, et al. The sleep phenotype of borderline personality disorder: a systematic review and metaanalysis. Neurosci Biobehav Rev. 2017;73:48-67. doi:10.1016/j. neubiorev.2016.12.008

3. Lereya ST, Winsper C, Tang NKY, Wolke D. Sleep problems in childhood and borderline personality disorder symptoms in early adolescence. J Abnorm Child Psychol. 2017;45(1):193-206. doi:10.1007/s10802-016-0158-4

4. Morales-Muñoz I, Broome MR, Marwaha S. Association of parentreported sleep problems in early childhood with psychotic and borderline personality disorder symptoms in adolescence. JAMA Psychiatry. 2020;77(12):1256. doi:10.1001/jamapsychiatry.2020.1875

5. Crowell SE, Beauchaine TP, Linehan MM. A biosocial developmental model of borderline personality: elaborating and extending Linehan's theory. Psychol Bull. 2009;135(3):495-510. doi: $10.1037 / \mathrm{a} 0015616$

6. Thomas N, Gurvich C, Kulkarni J. Borderline personality disorder, trauma, and the hypothalamus-pituitary-adrenal axis. Neuropsychiatr Dis Treat. 2019;15:2601-2612. doi:10.2147/NDT.S198804

7. Nicolaides NC, Vgontzas A, Kritikou I, Chrousos G. HPA Axis and Sleep. South Dartmouth (MA): MDText.com, Inc.; 2020.

8. Zeiders KH, Doane LD, Adam EK. Reciprocal relations between objectively measured sleep patterns and diurnal cortisol rhythms in late adolescence. $J$ Adolesc Health. 2011;48(6):566-571. doi:10.1016/j.jadohealth.2010.08.012

9. Pesonen A-K, Martikainen S, Kajantie E, et al. The associations between adolescent sleep, diurnal cortisol patterns and cortisol reactivity to dexamethasone suppression test. Psychoneuroendocrinology. 2014;49:150-160. doi:10.1016/j.psyneuen.2014.07.005

10. LaVoy EC, Palmer CA, So C, Alfano CA. Bidirectional relationships between sleep and biomarkers of stress and immunity in youth. Int J Psychophysiol. 2020;158:331-339. doi:10.1016/j. ijpsycho.2020.10.010

11. Räikkönen K, Matthews KA, Pesonen A-K, et al. Poor sleep and altered hypothalamic-pituitary-adrenocortical and sympatho-adrenal-medullary system activity in children. $J$ Clin Endocrinol Metab. 2010;95(5):2254-2261. doi:10.1210/jc.2009-0943

12. Lemola S, Perkinson-Gloor N, Hagmann-von Arx P, et al. Morning cortisol secretion in school-age children is related to the sleep pattern of the preceding night. Psychoneuroendocrinology. 2015;52:297301. doi:10.1016/j.psyneuen.2014.12.007

13. El-Sheikh M, Buckhalt JA, Keller PS, Granger DA. Children's objective and subjective sleep disruptions: links with afternoon cortisol levels. Health Psychol. 2008;27(1):26-33. doi:10.1037/ 0278-6133.27.1.26

14. Pesonen A-K, Kajantie E, Heinonen K, et al. Sex-specific associations between sleep problems and hypothalamic-pituitary-adrenocortical axis activity in children. Psychoneuroendocrinology. 2012;37(2):238-248. doi:10.1016/j.psyneuen.2011.06.008

15. Fernandez-Mendoza J, Vgontzas AN, Calhoun SL, et al. Insomnia symptoms, objective sleep duration and hypothalamicpituitary-adrenal activity in children. Eur J Clin Invest. 2014;44 (5):493-500. doi:10.1111/eci.12263

16. Sadeh A, Raviv A, Gruber R. Sleep patterns and sleep disruptions in school-age children. Dev Psychol. 2000;36(3):291-301. doi:10.1037//0012-1649.36.3.291
17. Hatzinger M, Brand S, Perren S, et al. Electroencephalographic sleep profiles and hypothalamic-pituitary-adrenocortical (HPA)activity in kindergarten children: early indication of poor sleep quality associated with increased cortisol secretion. $J$ Psychiatr Res. 2008;42(7):532-543. doi:10.1016/j.jpsychires.2007.05.010

18. Hatzinger M, Brand S, Perren S, et al. Sleep actigraphy pattern and behavioral/emotional difficulties in kindergarten children: association with hypothalamic-pituitary-adrenocortical (HPA) activity. J Psychiatr Res. 2010;44(4):253-261. doi:10.1016/j. jpsychires.2009.08.012

19. Saridjan NS, Kocevska D, Luijk MPCM, Jaddoe VW, Verhulst $\mathrm{FC}$, Tiemeier $\mathrm{H}$. The prospective association of the diurnal cortisol rhythm with sleep duration and perceived sleeping problems in preschoolers: the generation R study. Psychosom Med. 2017;79 (5):557-564. doi:10.1097/PSY.0000000000000440

20. Kiel EJ, Hummel AC, Luebbe AM. Cortisol secretion and change in sleep problems in early childhood: moderation by maternal overcontrol. Biol Psychol. 2015;107:52-60. doi:10.1016/j. biopsycho.2015.03.001

21. New AS, Hazlett EA, Buchsbaum MS, et al. Amygdala-prefrontal disconnection in borderline personality disorder. Neuropsychopharmacology. 2007;32(7):1629-1640. doi:10.1038/ sj.npp. 1301283

22. De La Fuente JM, Goldman S, Stanus E, et al. Brain glucose metabolism in borderline personality disorder. $J$ Psychiatr Res. 1997;31(5):531-541. doi:10.1016/s0022-3956(97)00001-0

23. New AS, Hazlett EA, Buchsbaum MS, et al. Blunted prefrontal cortical 18fluorodeoxyglucose positron emission tomography response to meta-chlorophenylpiperazine in impulsive aggression. Arch Gen Psychiatry. 2002;59(7):621-629. doi:10.1001/ archpsyc.59.7.621

24. Winsper C, Marwaha S, Lereya ST, Thompson A, Eyden J, Singh SP. A systematic review of the neurobiological underpinnings of borderline personality disorder (BPD) in childhood and adolescence. Rev Neurosci. 2016;27(8):827-847. doi:10.1515/revneuro2016-0026

25. Muzur A, Pace-Schott EF, Hobson JA. The prefrontal cortex in sleep. Trends Cogn Sci. 2002;6(11):475-481. doi:10.1016/s13646613(02)01992-7

26. Lunsford-Avery JR, Damme KSF, Engelhard MM, Kollins SH, Mittal VA. Sleep/wake regularity associated with default mode network structure among healthy adolescents and young adults. Sci Rep. 2020;10(1):509. doi:10.1038/s41598-019-57024-3

27. Cheng W, Rolls E, Gong W, et al. Sleep duration, brain structure, and psychiatric and cognitive problems in children. Mol Psychiatry. 2021;26(8):3992-4003. doi:10.1038/s41380-0200663-2

28. Urrila AS, Artiges E, Massicotte J, et al. Sleep habits, academic performance, and the adolescent brain structure. Sci Rep. 2017;7:41678. doi:10.1038/srep41678

29. Telzer EH, Fuligni AJ, Lieberman MD, Galván A. The effects of poor quality sleep on brain function and risk taking in adolescence. Neuroimage. 2013;71:275-283. doi:10.1016/j.neuroima ge.2013.01.025

30. Reidy BL, Hamann S, Inman C, Johnson KC, Brennan PA. Decreased sleep duration is associated with increased fMRI responses to emotional faces in children. Neuropsychologia. 2016;84:54-62. doi:10.1016/j.neuropsychologia.2016.01.028

31. Kocevska D, Muetzel RL, Luik AI, et al. The developmental course of sleep disturbances across childhood relates to brain morphology at age 7: the generation R study. Sleep. 2017;40(1). doi:10.1093/sleep/zsw022

32. Goldman S, D'Angelo E, DeMaso D. Psychopathology in the families of children and adolescents with borderline personality disorder. Am J Psychiatry. 1993;150(12):1832-1835. doi:10.1176/ ajp.150.12.1832 
33. Skoglund C, Tiger A, Rück C, et al. Familial risk and heritability of diagnosed borderline personality disorder: a register study of the Swedish population. Mol Psychiatry. 2021;26(3):999-1008. doi:10.1038/s41380-019-0442-0

34. Eyden J, Winsper C, Wolke D, Broome MR, MacCallum F. A systematic review of the parenting and outcomes experienced by offspring of mothers with borderline personality pathology: potential mechanisms and clinical implications. Clin Psychol Rev. 2016;47:85-105. doi:10.1016/j.cpr.2016.04.002

35. Field T, Diego M, Hernandez-Reif M, Figueiredo B, Schanberg S, Kuhn C. Sleep disturbances in depressed pregnant women and their newborns. Infant Behav Dev. 2007;30(1):127-133. doi:10.1016/j.infbeh.2006.08.002

36. Halal CS, Bassani DG, Santos IS, et al. Maternal perinatal depression and infant sleep problems at 1 year of age: subjective and actigraphy data from a population-based birth cohort study. $J$ Sleep Res. 2021;30(2):e13047. doi:10.1111/jsr.13047

37. O'Connor TG, Caprariello P, Blackmore ER, Gregory AM, Glover V, Fleming P. Prenatal mood disturbance predicts sleep problems in infancy and toddlerhood. Early Hum Dev. 2007;83 (7):451-458. doi:10.1016/j.earlhumdev.2006.08.006

38. Dias CC, Figueiredo B. Mother's prenatal and postpartum depression symptoms and infant's sleep problems at 6 months. Infant Ment Health J. 2020;41(5):614-627. doi:10.1002/imhj.21869

39. Dennis C-L, Ross L. Relationships among infant sleep patterns, maternal fatigue, and development of depressive symptomatology. Birth. 2005;32(3):187-193. doi:10.1111/j.0730-7659.2005.00368.x

40. Murray L. The impact of postnatal depression on infant development. J Child Psychol Psychiatry. 1992;33(3):543-561. doi:10.1111/j.1469-7610.1992.tb00890.x

41. Hiscock H, Wake M. Infant sleep problems and postnatal depression: a community-based study. Pediatrics. 2001;107(6):13171322. doi: $10.1542 /$ peds.107.6.1317

42. Stoléru S, Nottelmann ED, Belmont B, Ronsaville D. Sleep problems in children of affectively ill mothers. $J$ Child Psychol Psychiatry. 1997;38(7):831-841. doi:10.1111/j.1469-7610.1997. tb01601.x

43. Ystrom E, Hysing M, Torgersen L, Ystrom H, ReichbornKjennerud T, Sivertsen B. Maternal symptoms of anxiety and depression and child nocturnal awakenings at 6 and 18 months. J Pediatr Psychol. 2017;42(10):1156-1164. doi:10.1093/jpepsy/ jsx066

44. Petzoldt J, Wittchen H-U, Einsle F, Martini J. Maternal anxiety versus depressive disorders: specific relations to infants' crying, feeding and sleeping problems. Child Care Health Dev. 2016;42 (2):231-245. doi:10.1111/cch.12292

45. Reid GJ, Hong RY, Wade TJ. The relation between common sleep problems and emotional and behavioral problems among 2- and 3year-olds in the context of known risk factors for psychopathology. $J$ Sleep Res. 2009;18(1):49-59. doi:10.1111/j.1365-2869.2008.00692.x

46. Gregory AM, Eley TC, O'Connor TG, Rijsdijk FV, Plomin R. Family influences on the association between sleep problems and anxiety in a large sample of pre-school aged twins. Pers Individ Dif. 2005;39(8):1337-1348. doi:10.1016/j.paid.2005.06.008

47. Shang C-Y, Gau SS-F, Soong W-T. Association between childhood sleep problems and perinatal factors, parental mental distress and behavioral problems. J Sleep Res. 2006;15(1):63-73. doi:10.1111/j.1365-2869.2006.00492.x

48. Bat-Pitault F, Sesso G, Deruelle C, et al. Altered sleep architecture during the first months of life in infants born to depressed mothers. Sleep Med. 2017;30:195-203. doi:10.1016/j.sleep.2016.11.018

49. Martin J, Hiscock H, Hardy P, Davey B, Wake M. Adverse associations of infant and child sleep problems and parent health: an Australian population study. Pediatrics. 2007;119(5):947-955. doi:10.1542/peds.2006-2569
50. Warren SL, Gunnar MR, Kagan J, et al. Maternal panic disorder: infant temperament, neurophysiology, and parenting behaviors. $J$ Am Acad Child Adolesc Psychiatry. 2003;42(7):814-825. doi:10.1097/01.CHI.0000046872.56865.02

51. Schuetze P, Lawton D, Eiden RD. Prenatal cocaine exposure and infant sleep at 7 months of age: the influence of the caregiving environment. Infant Ment Health J. 2006;27(4):383-404. doi:10.1002/imhj.20097

52. Morales-Munoz I, Saarenpaa-Heikkila O, Kylliainen A, et al. The effects of maternal risk factors during pregnancy on the onset of sleep difficulties in infants at 3 months old. J Sleep Res. 2018;27 (5):e12696. doi:10.1111/jsr.12696

53. Seifer R, Sameroff AJ, Dickstein S, Hayden LC. Parental psychopathology and sleep variation in children. Child Adolesc Psychiatr Clin N Am. 1996;5(3):715-727. doi:10.1016/S10564993(18)30358-4

54. Agrawal HR, Gunderson J, Holmes BM, Lyons-Ruth K. Attachment studies with borderline patients: a review. Harv Rev Psychiatry. 2004;12(2):94-104. doi:10.1080/10673220490447218

55. Benoit D, Zeanah CH, Boucher C, Minde KK. Sleep disorders in early childhood: association with insecure maternal attachment. $J$ Am Acad Child Adolesc Psychiatry. 1992;31(1):86-93. doi:10.1097/00004583-199201000-00013

56. Simard V, Chevalier V, Bédard -M-M. Sleep and attachment in early childhood: a series of meta-analyses. Attach Hum Dev. 2017;19(3):298-321. doi:10.1080/14616734.2017.1293703

57. Belanger M-E, Bernier A, Simard V, Desrosiers K, Carrier J. Sleeping toward behavioral regulation: relations between sleep and externalizing symptoms in toddlers and preschoolers. J Clin Child Adolesc Psychol. 2018;47(3):366-373. doi:10.1080/ 15374416.2015.1079782

58. Pennestri M-H, Moss E, O’Donnell K, et al. Establishment and consolidation of the sleep-wake cycle as a function of attachment pattern. Attach Hum Dev. 2015;17(1):23-42. doi:10.1080/ 14616734.2014.953963

59. Simard V, Bernier A, Bélanger M-È, Carrier J. Infant attachment and toddlers' sleep assessed by maternal reports and actigraphy: different measurement methods yield different relations. J Pediatr Psychol. 2013;38(5):473-483. doi:10.1093/jpepsy/jst001

60. Beijers R, Jansen J, Riksen-Walraven $M$, de Weerth $C$. Attachment and infant night waking: a longitudinal study from birth through the first year of life. J Dev Behav Pediatr. 2011;32 (9):635-643. doi:10.1097/DBP.0b013e318228888d

61. Zentall SR, Braungart-Rieker JM, Ekas NV, Lickenbrock DM. Longitudinal assessment of sleep-wake regulation and attachment security with parents. Infant Child Dev. 2012;21(5):443-457. doi:10.1002/icd.1752

62. McNamara P, Belsky J, Fearon P. Infant sleep disorders and attachment: sleep problems in infants with insecure-resistant versus insecure-avoidant attachments to mother. Sleep Hypn. 2003;5(1):17-26.

63. Bilgin A, Wolke D. Infant crying problems and symptoms of sleeping problems predict attachment disorganization at 18 months. Attach Hum Dev. 2020;22(4):367-391. doi:10.1080/ 14616734.2019.1618882

64. Ibrahim J, Cosgrave N, Woolgar M. Childhood maltreatment and its link to borderline personality disorder features in children: a systematic review approach. Clin Child Psychol Psychiatry. 2018;23(1):57-76. doi:10.1177/1359104517712778

65. Greenfield EA, Lee C, Friedman EL, Springer KW. Childhood abuse as a risk factor for sleep problems in adulthood: evidence from a U.S. national study. Ann Behav Med. 2011;42(2):245-256. doi:10.1007/s12160-011-9285-x

66. Hamilton JL, Brindle RC, Alloy LB, Liu RT. Childhood trauma and sleep among young adults with a history of depression: a daily diary study. Front Psychiatry. 2018;9:673. doi:10.3389/fpsyt.2018.00673 
67. Kaubrys M, Baker MR, Frazier PA, Nguyen-Feng VN. Relations among daily stressors, childhood maltreatment, and sleep in college students. J Couns Psychol. 2021;68(4):489-500. doi:10.1037/ cou0000549

68. McPhie ML, Weiss JA, Wekerle C. Psychological distress as a mediator of the relationship between childhood maltreatment and sleep quality in adolescence: results from the Maltreatment and Adolescent Pathways (MAP) Longitudinal Study. Child Abuse Negl. 2014;38(12):2044-2052. doi:10.1016/j.chiabu.2014.07.009

69. Turner S, Menzies C, Fortier J, et al. Child maltreatment and sleep problems among adolescents in Ontario: a cross sectional study. Child Abuse Negl. 2020;99:104309. doi:10.1016/j.chiabu.2019.104309

70. Xiao D, Wang T, Huang Y, et al. Gender differences in the associations between types of childhood maltreatment and sleep disturbance among Chinese adolescents. J Affect Disord. 2020;265:595-602. doi:10.1016/j.jad.2019.11.099

71. Glod CA, Teicher MH, Hartman CR, Harakal T. Increased nocturnal activity and impaired sleep maintenance in abused children. J Am Acad Child Adolesc Psychiatry. 1997;36(9):1236-1243. doi:10.1097/00004583-199709000-00016

72. Wang Y, Raffeld MR, Slopen N, Hale L, Dunn EC. Childhood adversity and insomnia in adolescence. Sleep Med. 2016;21:1218. doi:10.1016/j.sleep.2016.01.011

73. Noll JG, Trickett PK, Susman EJ, Putnam FW. Sleep disturbances and childhood sexual abuse. J Pediatr Psychol. 2006;31(5):469480. doi:10.1093/jpepsy/jsj040

74. April-Sanders A, Duarte CS, Wang S, et al. Childhood adversity and sleep disturbances: longitudinal results in Puerto Rican children. Int J Behav Med. 2021;28(1):107-115. doi:10.1007/s12529-020-09873-w

75. Lieb K, Zanarini MC, Schmahl C, Linehan MM, Bohus M. Borderline personality disorder. Lancet (London, England). 2004;364(9432):453-461. doi:10.1016/S0140-6736(04)16770-6

76. Grant JE, Chamberlain SR. Sleepiness and impulsivity: findings in non-treatment seeking young adults. J Behav Addict. 2018;7 (3):737-742. doi:10.1556/2006.7.2018.71

77. Gershon A, Johnson SL, Thomas L, Singh MK. Double trouble: weekend sleep changes are associated with increased impulsivity among adolescents with bipolar I disorder. Bipolar Disord. 2019;21(2):132-141. doi:10.1111/bdi.12658

78. Rossa KR, Smith SS, Allan AC, Sullivan KA. The effects of sleep restriction on executive inhibitory control and affect in young adults. J Adolesc Health. 2014;55(2):287-292. doi:10.1016/j. jadohealth.2013.12.034

79. Fallone G, Acebo C, Arnedt JT, Seifer R, Carskadon MA. Effects of acute sleep restriction on behavior, sustained attention, and response inhibition in children. Percept Mot Skills. 2001;93 (1):213-229. doi:10.2466/pms.2001.93.1.213

80. Medeiros M, Carvalho LBC, Silva TA, Prado LBF, Prado GF Sleep disorders are associated with impulsivity in school children aged 8 to 10 years. Arq Neuropsiquiatr. 2005;63(3B):761-765. doi:10.1590/s0004-282x2005000500008

81. Gruber R, Cassoff J, Frenette S, Wiebe S, Carrier J. Impact of sleep extension and restriction on children's emotional lability and impulsivity. Pediatrics. 2012;130(5):e1155-61. doi:10.1542/peds.2012 0564

82. Daros AR, Williams GE, Meta-analysis A. Systematic review of emotion-regulation strategies in borderline personality disorder. Harv Rev Psychiatry. 2019;27(4):217-232. doi:10.1097/ HRP.0000000000000212

83. Williams KE, Berthelsen D, Walker S, Nicholson JM, Developmental Cascade A. Model of behavioral sleep problems and emotional and attentional self-regulation across early childhood. Behav Sleep Med. 2017;15(1):1-21. doi:10.1080/15402002.2015.1065410
84. Zhang J, Lau EYY, Hsiao JH-W. Using emotion regulation strategies after sleep deprivation: ERP and behavioral findings. Cogn Affect Behav Neurosci. 2019;19(2):283-295. doi:10.3758/s13415018-00667-y

85. Baum KT, Desai A, Field J, Miller LE, Rausch J, Beebe DW. Sleep restriction worsens mood and emotion regulation in adolescents. $J$ Child Psychol Psychiatry. 2014;55(2):180-190. doi:10.1111/ jcpp. 12125

86. Alfano CA, Bower JL, Harvey AG, Beidel DC, Sharp C, Palmer CA. Sleep restriction alters children's positive emotional responses, but effects are moderated by anxiety. J Child Psychol Psychiatry. 2020;61(10):1150-1159. doi:10.1111/ jcpp. 13287

87. Berger RH, Miller AL, Seifer R, Cares SR, LeBourgeois MK. Acute sleep restriction effects on emotion responses in 30- to 36month-old children. J Sleep Res. 2012;21(3):235-246. doi:10.1111/j.1365-2869.2011.00962.x

88. Palmer CA, Oosterhoff B, Bower JL, Kaplow JB, Alfano CA. Associations among adolescent sleep problems, emotion regulation, and affective disorders: findings from a nationally representative sample. J Psychiatr Res. 2018;96:1-8. doi:10.1016/j. jpsychires.2017.09.015

89. Grove JL, Smith TW, Crowell SE, Ellis JH. Preliminary evidence for emotion dysregulation as a mechanism underlying poor sleep quality in borderline personality disorder. J Pers Disord. 2017;31 (4):542-552. doi:10.1521/pedi 201630261

90. Wall K, Vanwoerden S, Penner F, Patriquin M, Alfano CA, Sharp C. Adolescent sleep disturbance, emotion regulation and borderline features in an inpatient setting. J Clin Child Adolesc Psychol. 2020;53:1-15. doi:10.1080/15374416.2020.1772081

91. Simor P, Csóka S, Bódizs R. Nightmares and bad dreams in patients with borderline personality disorder: fantasy as a coping skill? Eur J Psychiatry. 2010;24(1):28-37. doi:10.4321/S021361632010000100004

92. Bailey AJ, Finn PR. Borderline personality disorder symptom comorbidity within a high externalizing sample: relationship to the internalizing-externalizing dimensional structure of psychopathology. J Pers Disord. 2020;34(6):814-826. doi:10.1521/pedi_2019_33_415

93. Gregory AM, Rijsdijk FV, Dahl RE, McGuffin P, Eley TC. Associations between sleep problems, anxiety, and depression in twins at 8 years of age. Pediatrics. 2006;118(3):1124-1132. doi: $10.1542 /$ peds.2005-3118

94. Madrid-Valero JJ, Ronald A, Shakeshaft N, Schofield K, Malanchini M, Gregory AM. Sleep quality, insomnia, and internalizing difficulties in adolescents: insights from a twin study. Sleep. 2020;43(2). doi:10.1093/sleep/zsz229

95. Bai S, Ricketts EJ, Thamrin H, et al. Longitudinal study of sleep and internalizing problems in youth treated for pediatric anxiety disorders. J Abnorm Child Psychol. 2020;48(1):67-77. doi:10.1007/s10802-019-00582-x

96. Nunes S, Campbell MK, Klar N, Reid GJ, Stranges S. Relationships between sleep and internalizing problems in early adolescence: results from Canadian National Longitudinal Survey of Children and Youth. J Psychosom Res. 2020;139:110279. doi:10.1016/j.jpsychores.2020.110279

97. Chang L-Y, Chang H-Y, Wu W-C, Lin LN, Wu -C-C, Yen -L-L. Dual trajectories of sleep duration and cigarette smoking during adolescence: relation to subsequent internalizing problems. J Abnorm Child Psychol. 2018;46(8):1651-1663. doi:10.1007/s10802-0180414-X

98. Reynolds KC, Alfano CA. Childhood bedtime problems predict adolescent internalizing symptoms through emotional reactivity. $J$ Pediatr Psychol. 2016;41(9):971-982. doi:10.1093/jpepsy/jsw014 
99. Sivertsen B, Harvey AG, Reichborn-Kjennerud T, Ystrom E, Hysing M. Sleep problems and depressive symptoms in toddlers and 8-year-old children: a longitudinal study. J Sleep Res. 2021;30(1):e13150. doi:10.1111/jsr.13150

100. Hoyniak CP, Bates JE, McQuillan ME, et al. Sleep across early childhood: implications for internalizing and externalizing problems, socioemotional skills, and cognitive and academic abilities in preschool. J Child Psychol Psychiatry. 2020;61(10):10801091. doi:10.1111/jcpp. 13225

101. Muratori P, Menicucci D, Lai E, et al. Linking sleep to externalizing behavioral difficulties: a longitudinal psychometric survey in a cohort of Italian school-age children. J Prim Prev. 2019;40 (2):231-241. doi:10.1007/s10935-019-00547-2

102. Scharf RJ, Demmer RT, Silver EJ, Stein REK. Nighttime sleep duration and externalizing behaviors of preschool children. $J$ Dev Behav Pediatr. 2013;34(6):384-391. doi:10.1097/DBP.0b0 13e31829a7a0d

103. Lavigne JV, Arend R, Rosenbaum D, et al. Sleep and behavior problems among preschoolers. J Dev Behav Pediatr. 1999;20 (3):164-169. doi:10.1097/00004703-199906000-00005

104. Lee T, Kim J, Park KJ, Kim H-W. Sleep difficulties and related behavioral problems in Korean preschool children. Sleep Med. 2021;87:119-126. doi:10.1016/j.sleep.2021.09.002

105. Pieters S, Burk WJ, Van der Vorst H, Dahl RE, Wiers RW, Engels RCME. Prospective relationships between sleep problems and substance use, internalizing and externalizing problems. J Youth Adolesc. 2015;44(2):379-388. doi:10.1007/s10964-014-0213-9

106. Quach JL, Nguyen CD, Williams KE, Sciberras E. Bidirectional associations between child sleep problems and internalizing and externalizing difficulties from preschool to early adolescence. JAMA Pediatr. 2018;172(2):e174363. doi:10.1001/jamaped iatrics.2017.4363

107. Mulraney M, Giallo R, Lycett K, Mensah F, Sciberras E. The bidirectional relationship between sleep problems and internalizing and externalizing problems in children with ADHD: a prospective cohort study. Sleep Med. 2016;17:45-51. doi:10.1016/j. sleep.2015.09.019

108. Paavonen EJ, Porkka-Heiskanen T, Lahikainen AR. Sleep quality, duration and behavioral symptoms among 5-6-year-old children. Eur Child Adolesc Psychiatry. 2009;18(12):747-754. doi:10.1007/s00787-009-0033-8

109. Wong MM, Brower KJ, Zucker RA. Childhood sleep problems, early onset of substance use and behavioral problems in adolescence. Sleep Med. 2009;10(7):787-796. doi:10.1016/j. sleep.2008.06.015

110. Gruber R, Somerville G, Santisteban JA. Using parental report to identify children at risk for poor sleep and daytime problems. Behav Sleep Med. 2020;18(4):460-476. doi:10.1080/ 15402002.2019.1613236
111. Rubens SL, Evans SC, Becker SP, Fite PJ, Tountas AM. Selfreported time in bed and sleep quality in association with internalizing and externalizing symptoms in school-age youth. Child Psychiatry Hum Dev. 2017;48(3):455-467. doi:10.1007/s10578016-0672-1

112. Williamson AA, Mindell JA, Hiscock H, Quach J. Longitudinal sleep problem trajectories are associated with multiple impairments in child well-being. J Child Psychol Psychiatry. 2020;61 (10):1092-1103. doi:10.1111/jcpp.13303

113. Morales-Muñoz I, Lemola S, Saarenpää-Heikkilä O, et al. Parentreported early sleep problems and internalising, externalising and dysregulation symptoms in toddlers. BMJ Paediatr Open. 2020;4 (1):e000622. doi:10.1136/bmjpo-2019-000622

114. Cho S, Philbrook LE, Davis EL, Buss KA. Sleep duration and RSA suppression as predictors of internalizing and externalizing behaviors. Dev Psychobiol. 2017;59(1):60-69. doi:10.1002/ dev. 21467

115. Mindell JA, Leichman ES, DuMond C, Sadeh A. Sleep and social-emotional development in infants and toddlers. J Clin Child Adolesc Psychol. 2017;46(2):236-246. doi:10.1080/ 15374416.2016.1188701

116. Sivertsen B, Harvey AG, Reichborn-Kjennerud T, Torgersen L, Ystrom E, Hysing M. Later emotional and behavioral problems associated with sleep problems in toddlers: a longitudinal study. JAMA Pediatr. 2015;169(6):575-582. doi:10.1001/jamaped iatrics.2015.0187

117. Alfano CA, Zakem AH, Costa NM, Taylor LK, Weems CF. Sleep problems and their relation to cognitive factors, anxiety, and depressive symptoms in children and adolescents. Depress Anxiety. 2009;26(6):503-512. doi:10.1002/da.20443

118. Conway A, Miller AL, Modrek A. Testing reciprocal links between trouble getting to sleep and internalizing behavior problems, and bedtime resistance and externalizing behavior problems in toddlers. Child Psychiatry Hum Dev. 2017;48(4):678689. doi:10.1007/s10578-016-0692-x

119. Winsper C, Bilgin A, Wolke D. Associations between infant and toddler regulatory problems, childhood co-developing internalising and externalising trajectories, and adolescent depression, psychotic and borderline personality disorder symptoms. J Child Psychol Psychiatry. 2020;61(2):182-194. doi:10.1111/jcpp.13125

120. Reeve S, Emsley R, Sheaves B, Freeman D. Disrupting sleep: the effects of sleep loss on psychotic experiences tested in an experimental study with mediation analysis. Schizophr Bull. 2018;44 (3):662-671. doi:10.1093/schbul/sbx103

121. Fedak KM, Bernal A, Capshaw ZA, Gross S. Applying the Bradford Hill criteria in the 21st century: how data integration has changed causal inference in molecular epidemiology. Emerg Themes Epidemiol. 2015;12:14. doi:10.1186/s12982-015-0037-4
Nature and Science of Sleep

\section{Publish your work in this journal}

Nature and Science of Sleep is an international, peer-reviewed, open access journal covering all aspects of sleep science and sleep medicine, including the neurophysiology and functions of sleep, the genetics of sleep, sleep and society, biological rhythms, dreaming, sleep disorders and therapy, and strategies to optimize healthy sleep.
The manuscript management system is completely online and includes a very quick and fair peer-review system, which is all easy to use. Visit http://www.dovepress.com/testimonials.php to read real quotes from published authors. 